\title{
Impact of contaminated sediment elutriate on coastal phytoplankton community (Thau lagoon, Mediterranean Sea, France)
}

\author{
Ben Othman Hiba ${ }^{1,2}$, Pringault Olivier ${ }^{3}$, Louati Héla ${ }^{1}$, Sakka Hlaili Asma ${ }^{1}$, Leboulanger Christophe ${ }^{2,{ }^{*}}$ \\ ${ }^{1}$ Université de Carthage, Zarzouna, 7021 Bizerte, Tunisia \\ 2 IRD-CNRS-Université Montpellier-Ifremer, Station Marine, 2 rue des Chantiers, 34200 Sète, France \\ ${ }^{3}$ IRD, BP 434, 2 rue des Sports, El Menzah I, 1004 Tunis, Tunisia \\ *Corresponding author : Christophe Leboulanger, email address : christophe.leboulanger@ird.fr
}

\begin{abstract}
:
Effects of sediment-released contaminants and nitrogen were assessed on phytoplankton communities sampled from Thau lagoon (France, Mediterranean Sea) and one close offshore marine station. Phytoplankton was exposed to sediment elutriate (seawater containing a mix of metals, organic chemicals, and nutrients) or to ammonium enrichment for four days using immersed microcosms exposed to natural conditions of light and temperature. Functional (production - respiration balance) and structural (taxonomy and cell densities) responses of the phytoplankton community were assessed. In the lagoon, both treatments stimulated phytoplankton growth, compare to controls. Conversely in the offshore station, the phytoplankton growth was stimulated only with the sediment elutriate addition. In offshore and lagoon stations, both treatments caused a shift in the taxonomic composition of the phytoplankton. Proliferation of potentially toxic diatoms and dinoflagellates resulted from the addition of elutriate. Correspondence analysis determined that phytoplankton from the offshore station was more sensitive to both treatments compared to the lagoon community. According to daily production and respiration balance, lagoon community metabolism remained heterotrophic $(P<R)$ for all treatments, whereas only transient shifts to net autotrophy $(P>R)$ were observed in the offshore community. Direct toxicity of contaminants released from sediment, if any, was therefore masked by nutrient enrichment effects, whereas indirect evidence of contaminant pressure was highlighted by changes in community composition and metabolism.
\end{abstract}




\section{Highlights}

- Contaminated sediment elutriates trigger changes in phytoplankton dynamics. Phytoplankton community structure and metabolism are affected. Elutriates effects are not identical to those of nutrient addition alone. Elutriates effects differ depending on the initial community structure.

Keywords : Sediment resuspension, Mediterranean lagoon, Contaminants, Nutrients, Phytoplankton community 


\section{Introduction}

Anthropogenic contaminants in marine ecosystems are often eventually trapped by sediments, which act as a sink for pollutants. Resulting contaminated sediments affect mainly the benthic organisms but can also impede pelagic compartments when chemicals are released to the water column (Birch and O'Hea 2007; Jonas and Millward 2010; Roberts, 2012). Disturbance of contaminated sediments by anthropogenic (dredging and disposal of dredged materials, trawling, ship movements and propeller wash) and natural processes (tides, storms and bioturbation) may affect a wide range of species, eventually being incorporated into food webs (Burton and Johnston 2010). Resuspension of contaminated sediments (RCS) has been shown to be an important source of dissolved chemicals in historically contaminated estuaries (Kalnejais et al. 2010, Roberts 2012). Dissolved polycyclic aromatic hydrocarbon (PAH) and polychlorinated biphenyl (PCB) concentrations have been shown to increase due to dredged material disposal, even though the levels did not exceed water quality criteria (Cornelissen et al., 2008). For example, in conditions of turbulent mixing in oxygenated seawater, organic (PAH and $\mathrm{PCB}$ ) and inorganic (trace metals) contaminants were desorbed from sediments (Josefsson et al., 2010; Voie et al., 2002). In anthropized coastal areas, such mixing events also cause nutrients release, with consequent enrichment of the water column (Cantwell et al., 2002; Kalnejais et al., 2010), and ammonia may be released in greater amounts (Jones-Lee and Lee, 2005). A few studies have reported that nutrients and contaminants may have opposite results, with the beneficial effect of the nutrients overcompensating for the detrimental impact of the contaminants (Crain et al., 2008). The effects of RCS on pelagic organisms are still being studied and have not yet been fully incorporated into ecological risk assessment for management of coastal ecosystems (Roberts, 2012). Several studies have shown that marine organisms (such as fish, bivalves, algae and polychaetes) are sensitive to RCS by many pathways (Edge et al., 2015; Edge et al., 2016, Hill et al., 2009; Tolhurst et al., 2007; Voie et al., 2002).

Phytoplankton feeds pelagic food webs and determines aquatic ecosystem primary production and functioning at higher trophic levels (Field et al., 1998). Any change in its community structure and 
metabolism may, therefore, trigger a cascade of indirect effects throughout the plankton ecosystem (De Hoop et al., 2013). Understanding how phytoplankton responds to contaminants is of primary importance for forecasting the ecological consequences of chemical contamination and for targeting priority management and restoration policies for aquatic systems. There is however no general consensus about the responses of primary producers, in direction and extent, to the simultaneous load of pollutants and nutrients. For example, Riedel et al. (2003) reported that phytoplankton growth was inhibited after exposure to a combination of contaminants (mix of trace metals) and nutrients, whereas Lafabrie et al. (2013a, 2013b) showed that RCS can stimulate growth and modify phytoplankton community structure, suggesting that the toxic effect of chemicals if any could be offset by nutrients.

Within the marine environment, coastal ecosystems such as lagoons have become particularly impacted by chemical pollutants from anthropogenic inputs (agricultural, urban, and industrial) (Lafabrie et al., 2013a; Levin et al., 2001). This increased chemical contamination can cause a drastic alteration of the lagoon environment and eventually a threat to the services associated with lagoon environments (fisheries, aquaculture, tourism).This is the case for example of Thau lagoon (France), located on the northern shores of the Western Mediterranean Sea. The Thau Lagoon is one of the largest French Mediterranean Lagoons and is one the most important shellfish farming areas in Europe (Castro-Jimenez et al., 2008). It sustains a large population of exploited fish (gilthead seabream Sparus aurata and European seabass Dicentrarchus labrax) and reared shellfish (mussels, clams and oysters) (Fouilland et al., 2012). This lagoon appears to be under intense anthropogenic pressure characterized by an increase in industrial, agricultural and urban activities (La Jeunesse, 2001). Recent studies in the Thau lagoon have revealed moderate to high chemical contamination in the sediment (Rigollet et al., 2004), and high nutrient enrichment of the water (Anschutz et al., 2007; Fouilland et al., 2012) whereas the combined effects of pollutants and nutrients on the planktonic organisms of the lagoon have retained lesser attention. The Thau lagoon like all shallow marine ecosystems is subject to sediment resuspension that may have important consequences for the 
ecosystem functioning, and impact aquaculture activities (changes in the structure and contribution of potentially toxic phytoplankton for example). Among factors that can trigger resuspension (reviewed in Roberts, 2012) in the area, flash floods and windstorms are documented (Fouilland et al. 2012), together with dredging activities in the nearby waterways and harbor. This study aimed to assess the effects of elutriates prepared from RCS on the structure and the functioning of the Thau Lagoon phytoplankton community incubated under natural outdoor conditions of temperature and irradiance, compared to near coastal community, as well as on the dynamics and metabolism of autotrophic and heterotrophic compartments. The present work focused on the soluble fraction resulting from sediment resuspension considered as directly bioavailable for plankton communities, taking in mind that suspended sediment itself is prone to have different effects even trough physical damage (Edge et al., 2015; Edge et al., 2016). The two stations were chosen to compare the responses of a pre-exposed community from a closed lagoon, subjected to local inputs of contaminants to an a priori unexposed community from offshore station, considered as a reference.

\section{Materials and Methods}

\subsection{Study area}

The Thau lagoon, one of the largest French Mediterranean Lagoons $\left(43^{\circ} 24^{\prime} \mathrm{N}-3^{\circ} 36^{\prime} \mathrm{E}\right.$; Fig. 1$)$ with an area of $70 \mathrm{~km}^{2}$, is an important shellfishing area. Climate is characterized by autumnal storm events, and a single flood can contribute a quarter of the annual nitrogen supply from watershed (Tournoud et al., 2006). Consequently, dissolved ammonium, especially in the oyster farming areas, can reach a significant concentration (Fouilland et al., 2012; Gilbert et al., 1997). Thau lagoon has also been strongly affected by industrial activities and an intense urbanization since the mid $20^{\text {th }}$ century, which have resulted in a significant concentration of contaminants in sediments including polycyclic aromatic hydrocarbons PAH (440-7700 $\left.\mathrm{g} \mathrm{Kg}^{-1}\right)$, polychlorobyphenyls PCB $\left(600-30,000 \mathrm{ng} \mathrm{Kg}^{-1}\right)$, trace metals (8.9-6098 $\left.\mathrm{ng} \mathrm{g}^{-1}\right)$ and pesticides $\left(2921 \mathrm{ng} \mathrm{Kg}^{-1}\right)$ as reported in several studies (Kawakami et al., 2008; Léauté, 2008; Rigollet et al., 2004). 


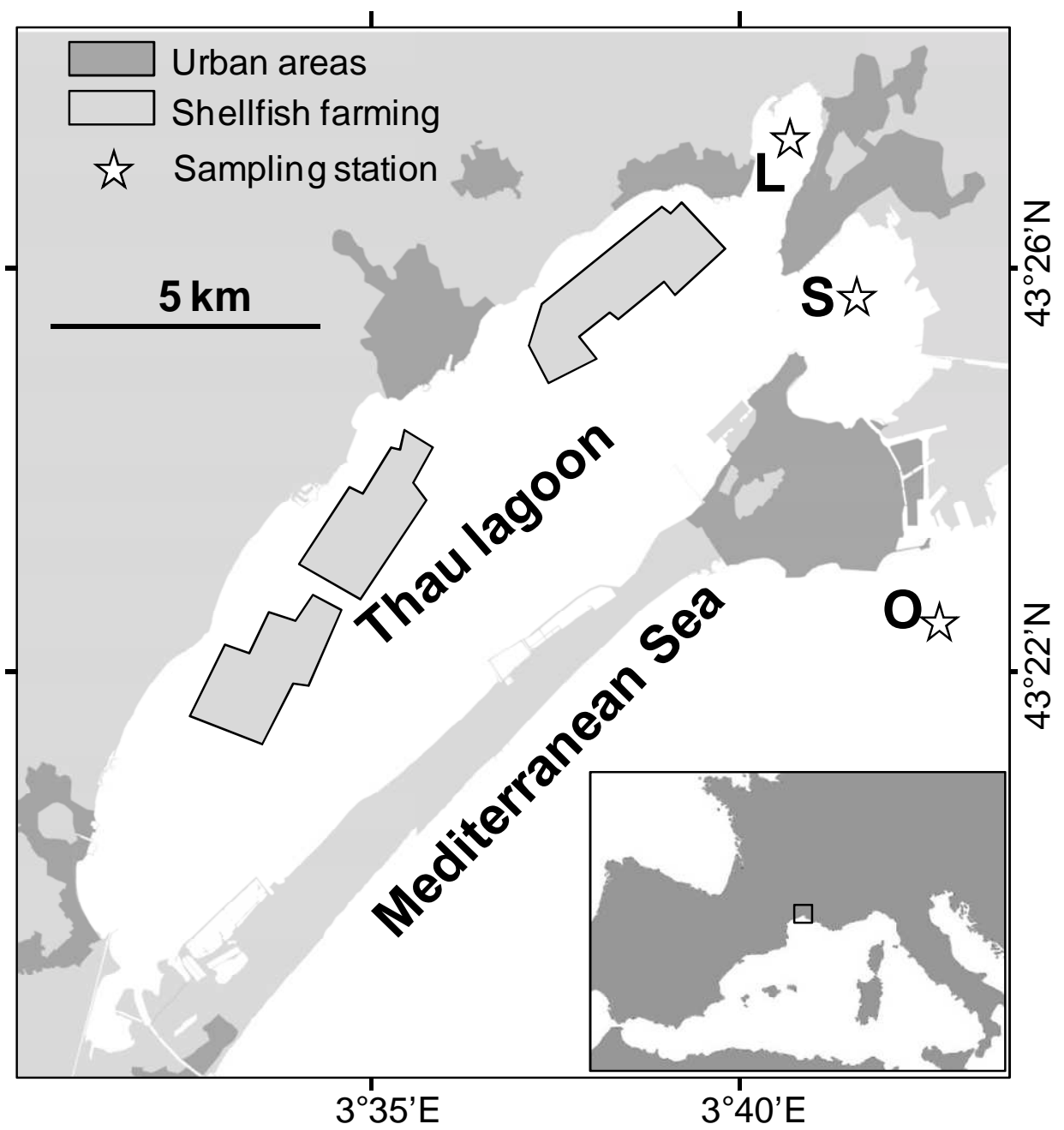

Figure 1. Situation of the Thau Lagoon in Southern France, and location of sampling stations: sediment and water for elutriate preparation(S), lagoon (L) and offshore (O) water inoculum.

\subsection{Sediment elutriate preparation and chemical analyses}

Water and sediment were sampled in June 2011 in the "Eaux Blanches" bay (Station S, Fig. 1). The sediments in this area have previously been characterized as highly contaminated by trace metals, PAH and PCB (Kawakami et al., 2008; Léauté, 2008). The sediment was sampled using a Van Veen grab and screened directly through a $2 \mathrm{~mm}$ mesh stainless steel sieve to remove stones, macrofauna and plant fragments. Water for elutriate preparation was collected from the surface in a bucket and immediately filtered through a $80 \mu \mathrm{m}$ mesh to remove the largest organisms and debris. The sediment elutriate was prepared as described by Bonnet et al. (2000). Sediment was stirred in water (ratio 1:4 v:v) for $8 \mathrm{~h}$ to mimic resuspension. After settling for $8 \mathrm{~h}$, the supernatant was collected and 
133

134

135

136

137

138

139

140

141

142

then filtered through 1 and $0.2 \mu \mathrm{m}$ membranes to remove any native microorganisms and leave only dissolved chemical contaminants. The elutriate was used as contaminated water (CW) for the microcosm experiment.

Ammonium concentration in the elutriate was measured spectrophotometrically using indophenol blue complexation in basic medium (Koroleff, 1969), with a detection limit of $0.04 \mu \mathrm{M}$.

Sub-samples of sediment and elutriates were preserved for further determination of 16 PAHs (naphthalene, acenaphthylene, fluorene, phenanthrene, anthracene, fluoranthene, pyrene, benzo(a)anthracene, chrysene, benzo(b)fluoranthene, benzo(k)fluoranthene, benzo(a)pyrene, dibenzo(a,h)anthracene, benzo(ghi)perylene, indeno(1,2,3-cd)pyrene and acenaphthylene) and 7 PCB congeners $(180,28,52,101,118,138$, and 153$)$ by GC-MS method after liquid-liquid extraction for the CW and soxhlet extraction for the sediment. Trace metals ( $\mathrm{As}, \mathrm{Cd}, \mathrm{Cr}, \mathrm{Cu}, \mathrm{Hg}, \mathrm{Ni}, \mathrm{Pb}, \mathrm{Zn}, \mathrm{U}, \mathrm{V}, \mathrm{Mn}$,

$\mathrm{Fe}, \mathrm{Co}$ and $\mathrm{Mo}$ ) concentrations in elutriate were measured by ICP-MS, and the $\mathrm{NH}_{4}{ }^{+}$concentration in the CW was determined using fluorometry (Holmes et al., 1999). Analytical methods involved the use of spiked deuterated standards and Canadian National Research Council standard seawater, for PAH and metal analysis respectively as described in Pringault et al. (2016).

Contaminant concentrations were compared when available to published quality guidelines and effects evaluation such as Effect Range Low and Effect Range Median (ERL and ERM, Long et al,. 1995), and harmful concentrations for $5 \%$ of tested species (HC5, Ben Othman et al., 2012, Wang et al., 2014, Wheeler et al., 2002) for sediment and water respectively.

\subsection{Outdoor microcosm experiment}

Seawater was sampled at station L (“Lagoon"), a highly-contaminated lagoon area characterized by regular occurrences of toxic dinoflagellate blooms (Laabir et al., 2011) and station O ("Offshore") chosen as an offshore reference station (Fig. 1). Water samples (50 L), collected from $0-2 \mathrm{~m}$ depth, was immediately filtered through an $80 \mu \mathrm{m}$ mesh to remove large grazers and particles, and then stored in the dark in coolers at ambient temperature before processing. Eighty $\mu \mathrm{m}$-filtered water 
(FW) was used as plankton inoculum in microcosms, submitted to three different treatments: sediment elutriate addition ( $\mathrm{E}: 3 \mathrm{~L}$ of $\mathrm{FW}+1 \mathrm{~L}$ of $\mathrm{CW}$ ), N-nutrient addition (N: $4 \mathrm{~L}$ of $\mathrm{FW}+20 \mu \mathrm{M}$ of $\mathrm{NH}_{4}{ }^{+}$, final concentration, close to the actually measured ammonium concentration in elutriate) and control with no addition ( $\mathrm{C}$ : $4 \mathrm{~L}$ of $\mathrm{FW}$ ). All treatments were performed in triplicate using $5 \mathrm{~L}$ glass bottles (Schott-Duran) which contained $1 \mathrm{~L}$ of air to allow gas exchange (de la Broise and Palenik, 2007). The E treatment (for elutriate) allowed the effect of both released pollutants and nutrients on the phytoplankton community to be determined, whereas $\mathrm{N}$ treatment investigated the impact of $\mathrm{NH}_{4}^{+}$enrichment alone. Ammonium was chosen because it is among the most significant $\mathrm{N}$ nutrients in the Thau lagoon prone to have direct effects on planktonic communities (Fouilland et al. 2012; Trottet et al. 2016).

All microcosms were incubated for $96 \mathrm{~h}$ in an outdoor tank exposed to natural sunlight and filled with seawater, which was renewed directly from the lagoon by a pumping-draining system allowing microcosms to support the same temperature as nearby seawater. This simulated the natural conditions of light and temperature of the Thau lagoon surface waters. Each microcosm was sampled at the beginning and at $24,48,72$ and $96 \mathrm{~h}$ of incubation to measure chl $a$ and plankton production and respiration. Sub-samples were also taken to determine the initial (at $0 \mathrm{~h}$ ) and final (at $96 \mathrm{~h}$ ) cell abundances and taxonomic composition of the phytoplankton communities.

\subsection{Chlorophyll $a$ analysis}

Sub-samples (200 $\mathrm{ml}$ ) for chl $a$ were filtered onto glass fiber filters (GF/F, Whatman), and immediately frozen at $-80^{\circ} \mathrm{C}$ until analysis. Chlorophyll $a$ was extracted using $90 \%$ acetone for $24 \mathrm{~h}$ in the dark at $4^{\circ} \mathrm{C}$, followed by ultrasonic grinding in an ice bath. After centrifugation of the extract (3500 rpm for $15 \mathrm{~min}$ ), pigment concentration in the supernatant was measured by spectrofluorimetry (Neveux and Lantoine, 1993).

\subsection{Phytoplankton identification and count}

To identify and count the phytoplankton, $250 \mathrm{ml}$ sub-samples were fixed with formaldehyde ( $4 \%$ final concentration). The phytoplankton cells were counted on a settled volume of $100 \mathrm{ml}$ (Utermöhl, 
1938), using an upright microscope (Zeiss AX10) with a Sony XCD- U100CR digital camera, or an inverted microscope (Olympus IX70) with a Moticam MoticamPro digital camera. At least 500 cells in each sample were counted to achieve reliable estimates.

\subsection{Production and respiration measurement}

The net primary production (NPP) and dark respiration $\left(R_{\text {dark }}\right)$ rates were measured using short time incubations $(<6 \mathrm{~h})$ in gas-tight $30 \mathrm{~mL}$ vessels, according to the oxygen light-dark incubation method (Pringault et al., 2007) with a Clark-type oxygen microsensor (Unisense, Denmark). Samples were kept at ambient field temperature and light irradiance during the incubation period. Oxygen concentrations were measured in each flask at one hour intervals, corrected for temperature, salinity and barometric pressure, and oxygen evolution rates calculated from linearized data providing hourly net primary production rates (NPP, $\mathrm{O}_{2}$ evolution in the light) and dark respiration rates $\left(\mathrm{R}_{\text {dark }}, \mathrm{O}_{2}\right.$ evolution in the dark). The gross primary production (GPP) was then calculated from the NPP and $R_{\text {light }}$ values $\left(G P P=\left|R_{\text {light }}\right|+N P P\right)$ considering that $R_{\text {light }}$ represented three times $R_{\text {dark }}$ following the procedure of Pringault et al. (2007). The primary production to community respiration ratios (P:R) were considered from the GPP and R daily rates that were calculated from the GPP $R_{\text {dark }}$ and $R_{\text {light }}$ hourly rates, respectively. A light period of $12 \mathrm{~h}$ was considered for integration of daily GPP rates, and daily respiration was calculated as the sum of hourly rates of $R_{\text {light }}(* 12$ hours) and hourly rates of $\mathrm{R}_{\text {dark }}(* 12$ hours $)$.

\subsection{Statistical analyses}

Differences in variables between treatments (fixed factor, 3 levels) and sampling times (fixed factor, 5 levels) were tested by two-way factorial analysis of variance (ANOVA). When ANOVA revealed significant differences, Tukey HSD post-hoc comparison test was performed to identify the significant differences. The conditions of distribution normality (Kolmogorov-Smirnov test) and variance homogeneity (Bartlett-Box test) were respected. These analyses were done using SPSS 14.0 statistical software for Windows. The Shannon-Wiener index $H$ was calculated using PAST freeware (Hammer and Harper, 2001) to analyze changes in phytoplankton diversity for each treatment. 
Correspondence analysis was performed using PAST from the absolute species abundances to detect

211 any phytoplankton composition change and highlight taxa most responsible for community

212 structuring.

213

214

215

216

217

218

219

220

221

222

223

224

225

226

227

\section{Results}

\subsection{Contaminant and nutrient levels}

Low levels of PCBs ranging from 0.002 to $0.017 \mu \mathrm{g} \mathrm{g}^{-1}$ were measured in the sediment, whereas greater amounts of PAHs were found (Table 1). The most abundant PAHs in sediment were fluoranthene $\left(1.7 \mu \mathrm{g} \mathrm{g}^{-1}\right)$, pyrene $\left(1.24 \mu \mathrm{g} \mathrm{g}^{-1}\right)$, benzo( $(a)$ anthracene $\left(0.78 \mu \mathrm{g} \mathrm{g}{ }^{-1}\right)$ and benzo(a)pyrene $\left(0.87 \mu g^{-1}\right)$

The contaminated water (CW) prepared from these sediment contained high metal levels at concentrations ranging from 0.03 (for Co) to $217.1 \mu \mathrm{g}^{-1}$ (for Mo) (Table 1). Apart from these potentially toxic contaminants, a significant concentration of $\mathrm{NH}_{4}{ }^{+}(21.8 \mu \mathrm{M})$ was also measured in CW. Elutriate did not contained any detectable dissolved PAH or PCB.

\begin{tabular}{|c|c|c|c|c|c|c|c|c|}
\hline & Sediment & $\mathrm{CW}$ & \multirow[b]{2}{*}{ PCB } & Sediment & CW & \multirow[b]{2}{*}{ TME } & Sediment & $\mathrm{CW}$ \\
\hline $\mathrm{PAH}$ & & & & & & & & \\
\hline Anthracene & 0.22 & bdl & PCB 101 & 0.002 & bdl & Mo & - & 217.1 \\
\hline Benzo(a)anthracene & 0.78 & bdl & PCB 118 & 0.012 & bdl & $\mathrm{Cd}$ & - & 0.021 \\
\hline Benzo(a)pyrene & 0.87 & bdl & PCB 138 & 0.005 & bdl & $\mathrm{Pb}$ & - & 0.088 \\
\hline Benzo(b)fluoranthene & 0.67 & bdl & PCB 135 & 0.007 & bdl & $U$ & - & 33.3 \\
\hline Benzo(g,h,i)perylene & 0.68 & bdl & PCB 180 & 0.017 & bdl & V & - & 3.91 \\
\hline Benzo(k)fluoranthene & 0.5 & bdl & PCB 28 & 0.01 & bdl & $\mathrm{Cr}$ & - & 0.47 \\
\hline Chrysene & 0.72 & bdl & PCB 52 & 0.006 & bdl & $\mathrm{Mn}$ & - & 22.67 \\
\hline Fluoranthene & 1.7 & bdl & & & & $\mathrm{Fe}$ & - & 1.53 \\
\hline Indenopyrene & 0.55 & bdl & & & & Co & - & 0.03 \\
\hline Naphthalene & 0.03 & bdl & & & & $\mathrm{Ni}$ & - & 0.62 \\
\hline Phenanthrene & 0.74 & bdl & & & & $\mathrm{Cu}$ & - & 2.49 \\
\hline Pyrene & 1.24 & bdl & & & & $\mathrm{Zn}$ & - & 1.75 \\
\hline & & & & & & As & - & 9.56 \\
\hline
\end{tabular}

Table 1. Contaminant levels in the Thau lagoon sediment ( $\mu \mathrm{g} \mathrm{g}^{-1} \mathrm{dry}$ weight) and in the prepared elutriate (CW, $\mu \mathrm{g} \mathrm{I}^{-1}$ ) (bdl: below detection limit of $0.01 \mu \mathrm{g} \mathrm{I}^{-1}$; -: not determined). PAH: polycyclic aromatic hydrocarbons; PCB: polychlorobyphenyl congeners; TME: trace metal elements.

\subsection{Effect of the treatments on chlorophyll $a$ concentrations}

In lagoon station L, the concentration of chl $a$ was $4.1 \mu \mathrm{gl}^{-1}$ in the inoculum, and after $24 \mathrm{~h}$, it increased 2 and 3 times compared to the control $\left(5.6 \mu \mathrm{g} \mathrm{I}^{-1}\right)$ in microcosms $\mathrm{E}$ (added CW) and $\mathrm{N}$ 
229 (added $\mathrm{NH}_{4}^{+}$), respectively (Fig. 2A). Levels remained significantly higher $(p<0.05)$ in $\mathrm{E}$ (average of $23011.24 \mu \mathrm{g} \mathrm{I}^{-1}$ ) and $\mathrm{N}$ (average of $12.25 \mathrm{~g} \mathrm{I}^{-1}$ ) than in the control (average $3.50 \mu \mathrm{g} \mathrm{I}^{-1}$ ) until the end of incubation (Fig. 2A) and no significant difference was observed between $\mathrm{E}$ and $\mathrm{N}$ treatment. By contrast, the concentration of chl $a$ was $0.225 \mathrm{\mu g}^{-1}$ in the inoculum from the offshore station $\mathrm{O}$. After $48 \mathrm{~h}$, it increased 6 and 13 times compared to the control in microcosms $\mathrm{E}$ (48h: $6.123 \mu \mathrm{g} \mathrm{I} \mathrm{I}^{-1}$ in $\mathrm{E}$ and $0.63 \mu \mathrm{g} \mathrm{I^{-1 }}$ in $\mathrm{C} ; 72 \mathrm{~h}: 13.21 \mu \mathrm{g} \mathrm{I}^{-1}$ in E and $0.7 \mu \mathrm{g} \mathrm{I}^{-1}$ in C) but at the end of the incubation the biomass decreased in microcosms $\mathrm{E}(p<0.05)\left(3.21 \mathrm{~g} \mathrm{~g}^{-1}\right)$. In general, no significant difference was observed between $\mathrm{C}$ and $\mathrm{N}$ treatments $(\mathrm{p}<0.05)$ for the offshore inoculum all along the experiment,

238

239

240
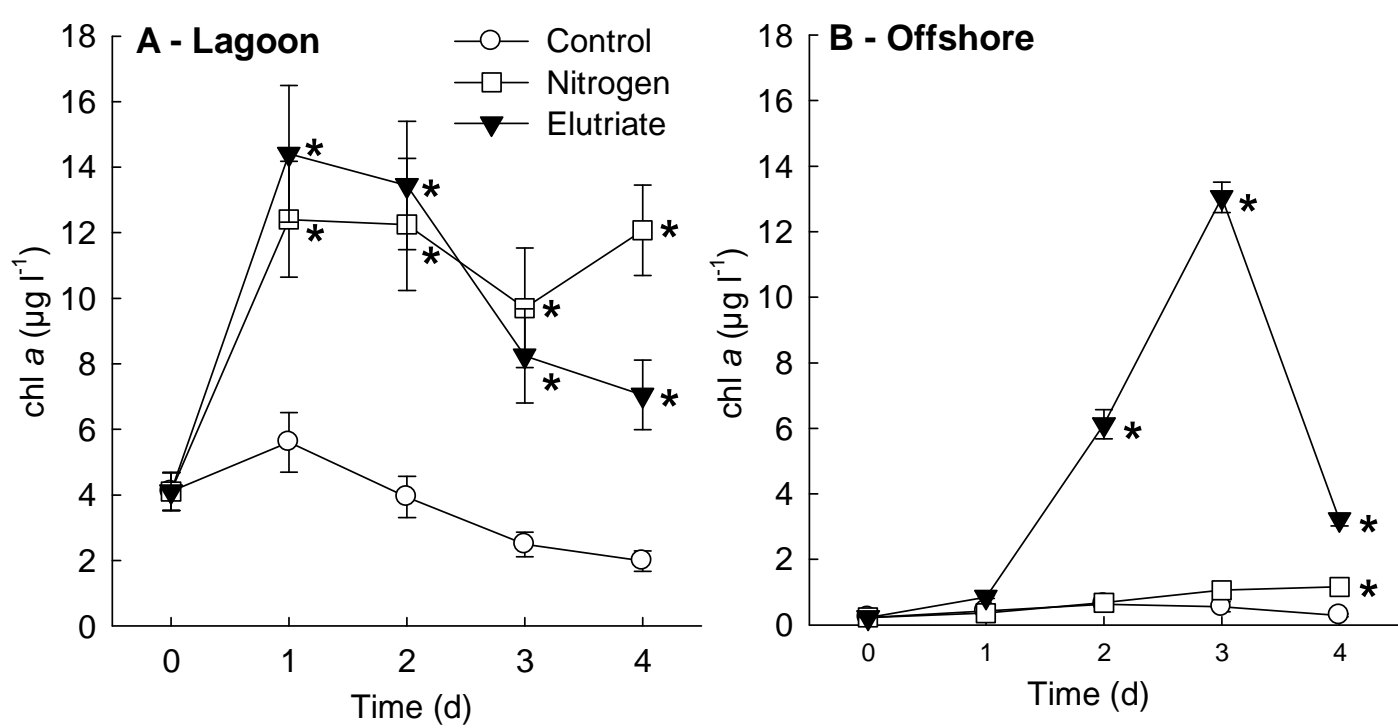

Figure 2. Evolution of chlorophyll $a$ concentrations in the microcosms for Lagoon (A) and Offshore experiments (B). Mean $\pm S E, n=3$.

\subsection{Effects of the treatments on phytoplankton abundance and whole community}

\section{composition}

In inoculums, the species diversity of the phytoplankton communities expressed as $H$ index was significantly lower in lagoon $\left(1.25 \pm 0.05\right.$ bits ind $\left.^{-1}\right)$ than in offshore station $\left(1.45 \pm 0.006\right.$ bits ind $\left.^{-1}\right)$.

\subsubsection{Lagoon phytoplankton community (station L)}


246 In station $L$, the phytoplankton inoculum $\left(0.8510^{6}\right.$ cells $\left.{ }^{-1}\right)$ was dominated by chrysophyceae $(0.38$

$24710^{6}$ cells $^{-1}$ ), the most abundant species being the loricate chromulinale Ollicola vangoorii (known as mixotrophic in Mediterranean waters, Novarino et al. 2002) and an unidentified chrysophyceae (50\% of total cell counts). The phytoplankton community contained similar proportions ( $25 \%)$ of dinoflagellates $\left(0.2110^{6}\right.$ cells I $\left.^{-1}\right)$ and small unidentified flagellates $\left(0.2310^{6}\right.$ cells I $\left.{ }^{-1}\right)$ (Fig. 3A).
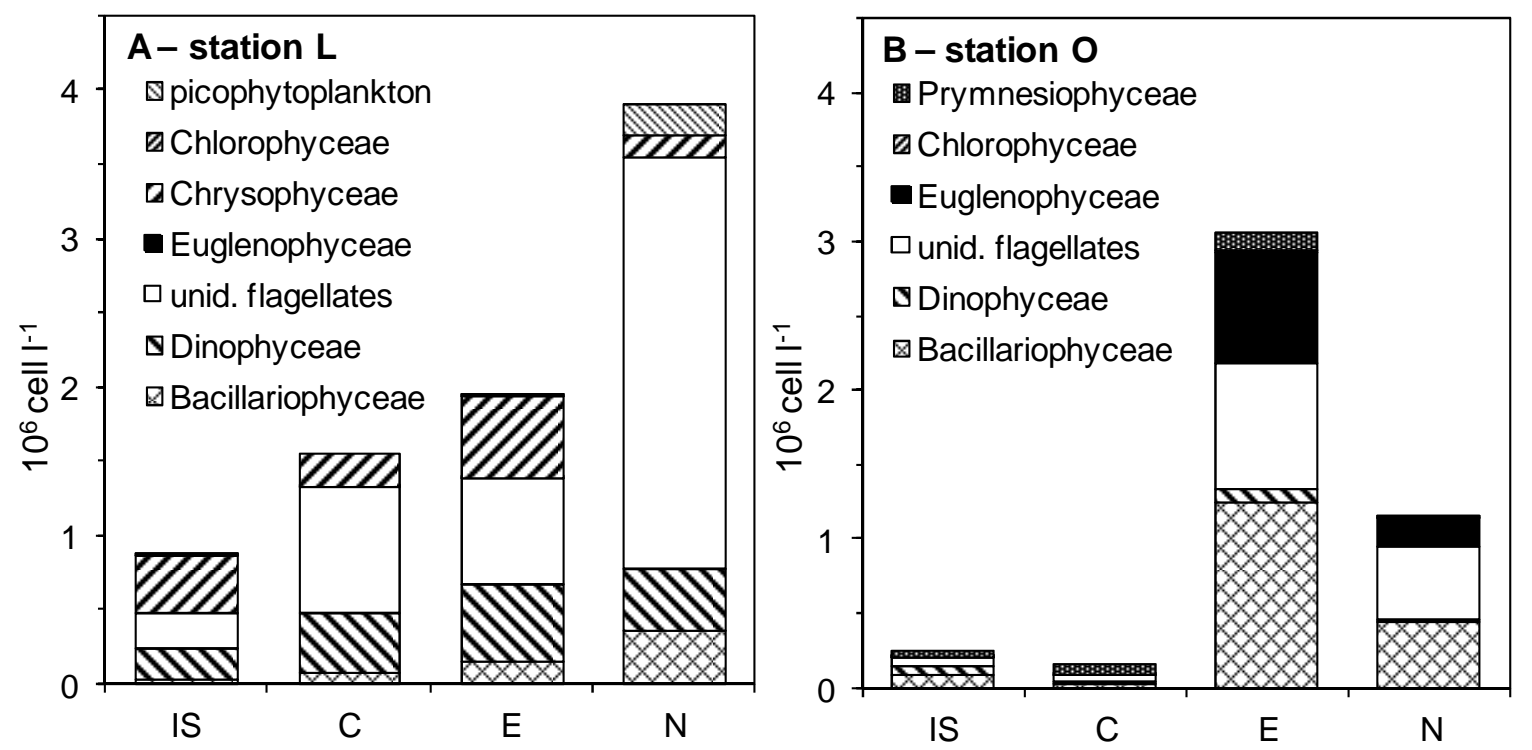

Figure 3. Contribution of the various taxonomic groups to the total phytoplankton abundances in the initial sample community (IS) and after four days in the control (C), sediment elutriate treatment (E), and nitrogen enrichment treatment (N) for Lagoon (Fig. 3A) and Offshore (Fig. 3B) experiments.

In station L, after $96 \mathrm{~h}$ of incubation, the phytoplankton density increased in all microcosms, reaching 1.54, 1.93 and $3.9010^{6}$ cells ${ }^{-1}$ in the C, E and $\mathrm{N}$ microcosms, respectively (Fig. 3A). Diatoms (0.06 $10^{6}$ cells $\mathrm{I}^{-1}$ in $\mathrm{C}, 0.1310^{6}$ cells $\mathrm{I}^{-1}$ in S), chrysophycea (Ollicola vangoorii and the unidentified

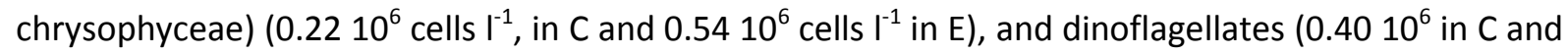
$0.5110^{6}$ cells $\mathrm{I}^{-1}$ in $\mathrm{E}$ ) were stimulated by the addition of elutriate. In the $\mathrm{N}$ microcosms, the flagellates density increased significantly $(74.9 \%)$ followed by the diatoms $(9 \%)$ and cyanobacteria $(5 \%)$, the community being dominated by the unidentified flagellates $(71 \%)$. By comparison, the community in the E microcosms comprised mainly dinoflagellates (11\%), chrysophyceae (3.9\%) and diatoms (9\%). The contribution of diatoms in the $\mathrm{N}$ microcosms (9\%) seemed to be higher than in the 
E microcosms (7.1\%). As well as changes in the contributions from the various taxonomic groups to the phytoplankton community, there were changes in the species composition inside taxonomic groups. Phytoplankton diversity increased after $96 \mathrm{~h}$ of incubation in all three microcosms compared to the initial samples. The Shannon index $H$ was $1.7 \pm 0.03 ; 1.55 \pm 0.02$ and $1.6 \pm 0.01$ bits ind $^{-1}$, respectively in C, E and $\mathrm{N}$ microcosms and there was no significant difference between treatments ( $p$ $>0.05)$.

\subsubsection{Offshore phytoplankton community (station O)}

In station $\mathrm{O}$, the initial community of phytoplankton $\left(0.2410^{6}\right.$ cells $\left.\mathrm{I}^{-1}\right)$ was dominated by diatoms $\left(0.08510^{6}\right.$ cells $\left.\mathrm{I}^{-1}\right)$ and dinophyceae $\left(0.05310^{6}\right.$ cells $\left.\mathrm{I}^{-1}\right)$. After $96 \mathrm{~h}$ of incubation, the algal density increased in $\mathrm{N}$ and $\mathrm{E}$ microcosms, respectively 1.25 and $3.0410^{6}$ cells $\mathrm{I}^{-1}$, compared to the control $\left(0.1510^{6}\right.$ cells $\left.\mathrm{I}^{-1}\right)$. Diatoms $\left(1.2410^{6}\right.$ cells I $^{-1}$ in E, $0.01410^{6}$ cells I $^{-1}$ in C), unidentified flagellates $(0.03$ $10^{6}$ cells $\mathrm{I}^{-1}$ in $\mathrm{C}$ and $0.8510^{6}$ cells $\mathrm{I}^{-1}$ in $\mathrm{E}$ ) and chrysophyceae ( 0 in $\mathrm{C}$ and $0.7310^{6}$ cells $\mathrm{I}^{-1}$ in $\mathrm{E}$ ) were stimulated by the addition of elutriate (Fig. 3B). In the $\mathrm{N}$ and $\mathrm{E}$ microcosms, the diatoms $(40.8 \%$ in $\mathrm{E}$ and $37.5 \%$ in $\mathrm{N}$ ) and chrysophyceae ( $24.3 \%$ in $\mathrm{E}$ and $16.1 \%$ in $\mathrm{N})$ were significantly increased compared to the control (Diatoms: $9.9 \%$; Chrysophyceae: $0 \%$ ). By contrast, dinoflagellates showed a sharp decrease in E (2.8\%) and $\mathrm{N}(1.4 \%)$ compared to the control (14.1\% of total cell densities). Unidentified flagellates were stimulated in E microcosms (42.6\%) compared to the control and $\mathrm{N}$ microcosms ( 23.7 and $28 \%$ respectively). In the offshore sample experiment, the diversities in C microcosms $\left(1.41 \pm 0.04\right.$ bits ind $\left.^{-1}\right)$ were significantly higher after $96 \mathrm{~h}$ than in $E\left(1.32 \pm 0.002\right.$ bits ind $\left.^{-1}\right)$ and $\mathrm{N}$ microcosms $\left(1.19 \pm 0.03\right.$ bits ind $\left.^{-1}\right)$.

\subsection{Effect of the treatments on diatom community composition}

In station $L$, the initial diatom community was dominated by three pennate taxa, the potentially toxic Pseudo-nitzschia sp. (43\%) and Nitzschia longissima (43\%), followed by Nitzschia sp. (14\%) (Table 2). After 4 days of incubation, the diatom diversity remained similar in the $\mathrm{C}$ and $\mathrm{N}$ microcosms, with a large contribution of Pseudo-nitzschia sp. (80-90\%) and a small contribution of Nitzschia longissima 
289 (5\%) (Table 2). Until the end of incubation time, Pseudo-nitzschia spp. were the only diatoms 290 remaining under elutriate addition (E microcosms).

\begin{tabular}{|c|c|c|c|c|c|c|c|c|}
\hline & \multicolumn{4}{|c|}{ Lagoon } & \multicolumn{4}{|c|}{ Offshore } \\
\hline & IS & C & $\mathrm{E}$ & $\mathrm{N}$ & IS & C & $E$ & $\mathrm{~N}$ \\
\hline Asterionellopsis glacialis & & & & & 31.4 & & & \\
\hline Chaetoceros spp. & & & & & 25.6 & 11.8 & 3.5 & 62.8 \\
\hline Leptocylindrus sp. & & & & & 4.1 & & & \\
\hline Nitzschia longissima & 42.9 & 4.8 & & 12.5 & 3.3 & & 2.7 & 3.3 \\
\hline Nitzschia sp. & 14.3 & & & & & & & \\
\hline Pseudo-nitzschia sp. & 42.9 & 90.5 & 100 & 87.5 & 35.5 & 76.5 & 90.3 & 29.5 \\
\hline Thalassiosira sp. & & & & & & 11.8 & 3.5 & 4.4 \\
\hline Unidentified diatoms & & 4.8 & & & & & & \\
\hline
\end{tabular}

291

292

293

294

295

296

297

Table 2. Diatom species composition (expressed as \% of total cell counts in the group) in initial sample community (IS) and after four days in the control (C), sediment elutriate treatment (E), and nitrogen enrichment treatment $(\mathrm{N})$ for lagoon and offshore experiments. Empty cells: taxa not found in the sample.

In the station $\mathrm{O}$, the initial community of diatoms (Table 2) was dominated by potentially toxic Pseudo-nitzschia spp. (35.5\%), Asterionellopsis glacialis (31.4\%) and Chaetoceros spp. (25.6\%). After 96h exposure, the two species Asterionellopsis glacialis and Leptocylindrus sp. disappeared in the three treatments. Conversely, the centric diatom Thalassiosira sp. appeared in large numbers in C (11.8 \%), N (4.4 \%) and E (3.5 \%) microcosms. The potentially toxic Pseudo-nitzschia spp. were the dominant diatom species in C and E microcosms (76.5\% and $90.3 \%$, respectively), accounting for a smaller contribution in $\mathrm{N}$ microcosms (29.5\%) compared to the control (Table 2).

\subsection{Effect of the treatments on dinoflagellate community composition}

In station $L$, at the beginning of the experiment, the dinophyceae were dominated by Alexandrium sp., which contributed up to $72 \%$ to total dinoflagellate community. The contributions of other species varied from $0.9 \%$ (Gonyaulax polygramma, Gonyaulax spinifera, Gyrodinium sp., Oblea sp., Prorocentrum lima and Protoperidinium sp.) to 5.2\% (Prorocentrum gracile and Gymnodinium sp.) (Table 3).

At the end of incubation, the genus Alexandrium was still the dominant one in all three microcosms ( $54.7 \%$ in C, $56.0 \%$ in E and $74.2 \%$ in N). There was also a significant development of Prorocentrum 
311 present in the control, disappeared from the $\mathrm{E}$ and $\mathrm{N}$ microcosms after the incubation.

Alexandrium sp.

Gonyaulax polygramma

Gonyaulax spinifera

Gymnodinium sp.

Gyrodinium sp.

Katodinium sp.

Neoceratium fusus

Oblea sp.

Peridinium quinquecorne

Prorocentrum gracile

Prorocentrum lima

Prorocentrum micans

Prorocentrum minimum

Prorocentrum sp.

Protoperidinium diabolus

Protoperidinium sp.

Scrippsiella sp.

Unidentified dinoflagellates

\begin{tabular}{|c|c|c|c|c|c|c|c|}
\hline \multicolumn{4}{|c|}{ Lagoon } & \multicolumn{4}{|c|}{ Offshore } \\
\hline IS & C & $E$ & $\mathrm{~N}$ & IS & C & $E$ & $\mathrm{~N}$ \\
\hline 72.4 & 54.7 & 56.1 & 74.2 & & & & \\
\hline 0.9 & & 0.6 & 2.2 & & & & \\
\hline 0.9 & & & & 1.9 & & & \\
\hline 5.2 & 13.1 & 19.5 & 5.6 & 52.8 & 51.6 & 57.1 & 16.7 \\
\hline 0.9 & 2.2 & 2.4 & & 17.0 & & & \\
\hline & 2.2 & & & & & & \\
\hline & & & & 1.9 & & & \\
\hline 0.9 & 0.7 & 0.6 & & & & & \\
\hline 2.6 & & 0.6 & & & & & \\
\hline 5.2 & 4.4 & 3.7 & 6.7 & & & & 16.7 \\
\hline 0.9 & & & & & & & \\
\hline 3.4 & & 4.3 & 1.1 & 3.8 & 9.7 & 14.3 & \\
\hline 2.6 & 1.5 & 1.2 & 5.6 & & 3.2 & & \\
\hline & & & & & 4.8 & & \\
\hline & 1.5 & & & & & & \\
\hline 0.9 & 0.7 & 1.2 & 3.4 & & & & \\
\hline 2.6 & 2.9 & 1.2 & 1.1 & 1.9 & 6.5 & & \\
\hline 0.9 & 16.1 & 8.5 & & 20.8 & 24.2 & 28.6 & 66.7 \\
\hline
\end{tabular}

Table 3. Dinoflagellates species composition (expressed as \% of total cell counts in the group) in initial sample community (IS) and after four days in the control (C), sediment elutriate treatment (E), and nitrogen enrichment treatment $(\mathrm{N})$ for lagoon and offshore experiments. Empty cells: taxa not found in the sample.

In station $\mathrm{O}$, the initial community of dinoflagellates was dominated by Gymnodinium spp. with

$52.83 \%$ of relative contribution (Table 3 ), followed by unidentified dinoflagellates $(20.8 \%)$ and Gyrodinium sp. (17\%). After 96h of incubation, Gymnodinium spp. were dominant in the control C (51.6 \%) and E treatment (57.1\%), followed by unidentified dinoflagellates (C: $24.2 \%$; E: $28.6 \%$ ). By contrast, unidentified dinoflagellates were most abundant in the $\mathrm{N}$ microcosms (66.7 \%) compared to Gymnodinium spp. and Gyrodinium sp. (16.7 \% for both).

\subsection{Effect of the treatments on the other phytoplankton community composition}

In station L, various flagellates belonging to several classes were present in the inoculum sample dominated by Ollicola vangoorii and colored flagellates, together with few cyanobacteria, chrysophyceae, unidentified chrysophyceae and chlorophyceae (Table 4). The chrysophyceae $O$. vangoorii was the dominant species (59.3\%). At the end of incubation, the contribution of $O$. vangoorii was lower in microcosms $\mathrm{C}(20.1 \%)$ and $\mathrm{N}(4.7 \%)$ relative to microcosms $\mathrm{E}(42.6 \%)$. There 

in $C, 56.4 \%$ in $E$ and $88.5 \%$ in N) than in the inoculum.

cyanobacteria chlorophyceae coccolithophorids

Eutreptiella braarudii Ollicola vangoorii Unidentified chysophyceae Unidentified flagellates

\begin{tabular}{cccc}
\multicolumn{4}{c}{ Lagoon } \\
IS & C & E & N \\
\hline 0.6 & & 0.5 & 6.6 \\
0.6 & & 0.2 &
\end{tabular}

$\begin{array}{ll}0.3 & 0.2\end{array}$

$\begin{array}{lll}59.3 & 20.1 & 42.6\end{array}$

$\begin{array}{ll}2.1 & 0.8\end{array}$

$\begin{array}{llll}37.4 & 78.8 & 56.4 & 88.5\end{array}$

\begin{tabular}{cccc}
\multicolumn{4}{c}{ Offshore } \\
IS & C & E & N \\
\hline & & & \\
2.2 & 9.8 & 0.6 & 1.8 \\
38.8 & 59.0 & 6.9 & 2.1 \\
& & & \\
2.8 & & 43.0 & 26.3 \\
& & & \\
56.2 & 31.1 & 49.6 & 69.8
\end{tabular}

330

331

332

333

334

335

336

Table 4. Chlorophyceae, cyanobacteria and pigmented flagellate species composition (expressed as $\%$ of total cell counts in the group) in initial sample community (IS) and after four days in the control $(C)$, sediment elutriate treatment $(E)$, and nitrogen enrichment treatment $(\mathrm{N})$ for lagoon and offshore experiments. Empty cells: taxa not found in the sample.

In station $\mathrm{O}$, the inoculum community was dominated by unidentified flagellates (56.2 \%) and coccolithophorids (38.8\%). The remaining part of cell density was constituted by Ollicola vangoori and unidentified chlorophycea. After 96h, unidentified flagellates were dominant in the two treatments $E$ and N (E: $49.6 \% ; \mathrm{N}: 69.8 \%$ ) compared to the control (31.1\%). The opposite pattern was noticed for coccolithophorids (C: $59.0 \%$; N: $2.1 \%$; E: $6.9 \%$ ). For the chrysophyceae Ollicola vangoorii, almost the same evolution pattern was observed as in the station $L$ with a large increase in cell numbers during the incubation. In fact, this species showed a higher contribution in E microcosms (43.0 \%) compared to the $\mathrm{N}(26.3 \%)$ and $\mathrm{C}(0 \%)$ ones (Table 4$)$.

\subsection{Correspondence analysis}

The correspondence analysis, of which the two main axes explained $60.4 \%$ of the observed variances, highlighted the marked changes between phytoplankton composition at the initial and the end of the experiments in the stations $L$ and $O$ (Fig. 4). In lagoon station $L$, the final community composition in $\mathrm{N}$ and $\mathrm{E}$ microcosms differed from inoculum and control microcosms. The average treatment effect was more pronounced in offshore station compared to the lagoon station. Results demonstrated a pronounced divergence between the initial samples used as inoculum and the two treatments $\mathrm{N}$ and $\mathrm{E}$ after incubation (Fig. 4), the control remaining close to the inoculum. The species Alexandrium sp., Chaetoceros sp., Pseudo-nitzschia sp., and Ollicola vangorii may have been mainly 
351

352

353

354

355

356

357

responsible for these differences between the different microcosms (inoculum, $\mathrm{C} \mathrm{N}$ and E). For the lagoon station, cyanobacteria Spirulina sp., and Prorocentrum species (P. micans, $P$. gracile and $P$. minimum) contributed to the difference between $\mathrm{E}$ treatment and the others (inoculum, $\mathrm{N}$ and $\mathrm{C}$ ), whereas Asterionellopsis glacialis, coccolithophorids, Prorocentrum micans, P. gracile, Gyrodinium sp. and unidentified flagellates may have been mainly responsible for these differences between the different samples (inoculum, $\mathrm{C}, \mathrm{N}$ and $\mathrm{E}$ ) in the station $\mathrm{O}$ (data not illustrated).

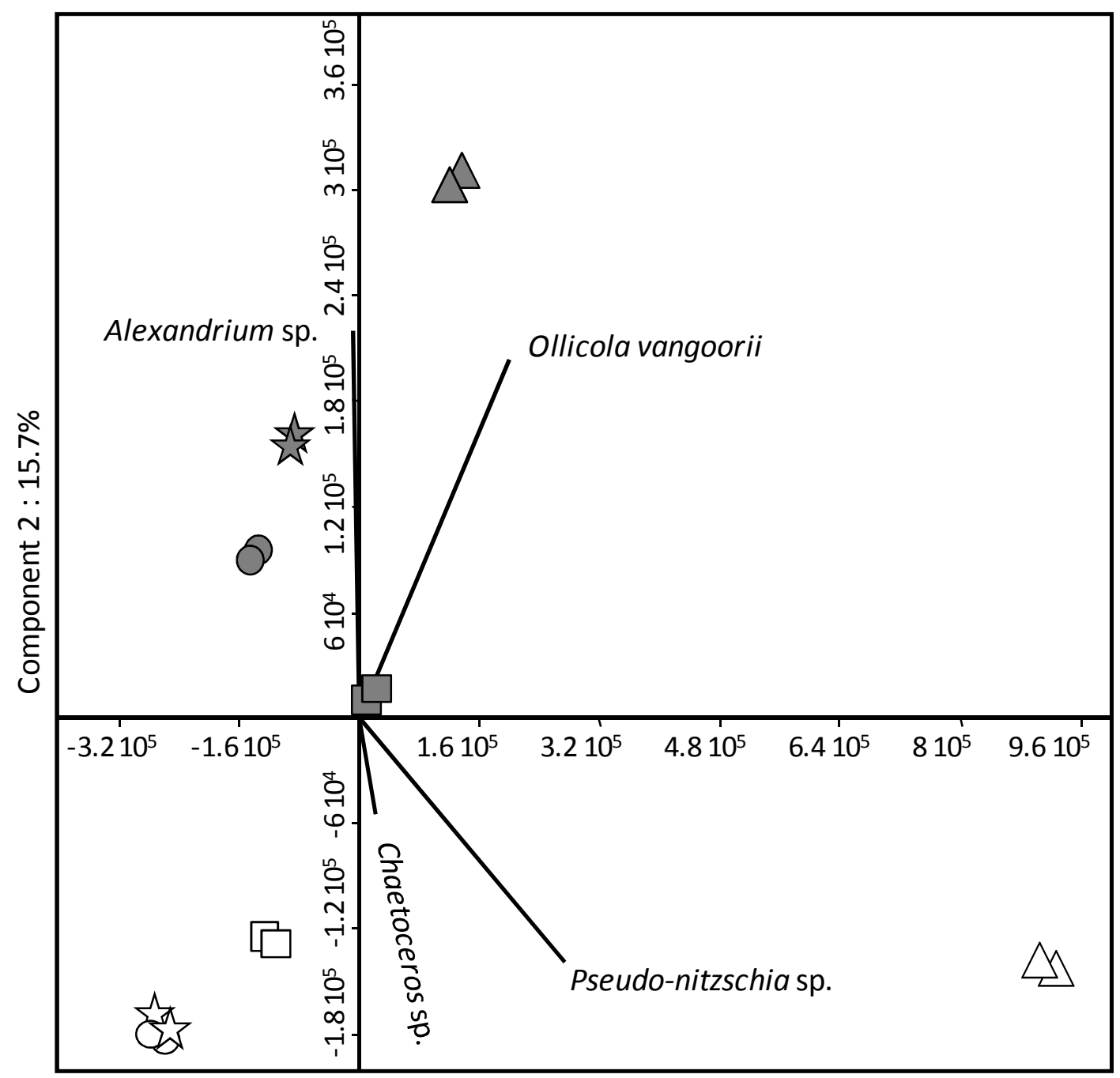

Component 1: $73.5 \%$

Figure 4. Correspondence analysis scatter plot obtained from the relative contributions of identified phytoplankton taxa for the Lagoon (grey symbols) and Offshore (open symbols) experiments. Stars: inoculum; circles: controls; squares: nitrogen enrichment; triangles: sediment elutriate treatment. Species with loadings $>0.5$ are shown. 


\subsection{Effect of the treatments on community metabolism: production and respiration}

363 In the lagoon station L, gross primary production (GPP) rates showed a peak $\left(>5 \mu \mathrm{mol} \mathrm{O}_{2} \mathrm{I}^{-1} \mathrm{~h}^{-1}\right)$ in nitrogen enriched microcosm relative to control and elutriate treatments after $48 \mathrm{~h}$ of incubation (Fig.

5A). Nevertheless, oxygen evolution rates were almost identical in $\mathrm{N}$ and $\mathrm{E}$ treatments for all the other incubation times, whereas GPP in controls was lower (below $2 \mu \mathrm{mol} \mathrm{O}_{2} \mathrm{I}^{-1} \mathrm{~h}^{-1}$ ) and decreased continuously, from start to $96 \mathrm{~h}$. Both incubation time and treatment modified to metabolic pattern (Table 5). In the offshore station, GPP values were significantly stimulated under the three treatments after a short time, from 0.9 to $3.43 \mu \mathrm{mol} \mathrm{O} \mathrm{I}^{-1} \mathrm{~h}^{-1}$ in $\mathrm{C}$, from 0.69 to $2.58 \mu \mathrm{mol} \mathrm{O} \mathrm{I}^{-1} \mathrm{~h}^{-1}$ in

$370 \mathrm{~N}$ and from 1.32 to $3.91 \mu \mathrm{mol} \mathrm{O}_{2} \mathrm{I}^{-1} \mathrm{~h}^{-1}$ in E microcosms (Fig. 5B). Accordingly, during the later part of

371 the incubation period, a decrease in GPP was noticed in the three microcosms. GPP rates were

372 significantly stimulated in $E$ microcosms compared to the $C$ and $N$ ones (Table $5, p<0.05$ ). The 373 average GPP rate was $3.03 \mu \mathrm{mol} \mathrm{O} \mathrm{I}^{-1} \mathrm{~h}^{-1}$ in $\mathrm{E}$, almost doubled compared to the $\mathrm{C}\left(1.55 \mu \mathrm{mol} \mathrm{O} \mathrm{O}^{-1} \mathrm{~h}^{-}\right.$

$374{ }^{1}$ ) and $\mathrm{N}$ microcosms $\left(1.56 \mu \mathrm{mol} \mathrm{O}_{2} \mathrm{I}^{-1} \mathrm{~h}^{-1}\right)$ (Fig. 5B).

\section{Lagoon}

\begin{tabular}{rcccccc} 
variable & treatment & time & interaction & E-C & N-C & E-N \\
\cline { 2 - 7 } chl $a$ & 0.0000 & 0.0000 & 0.0049 & $*$ & $*$ & $n s$ \\
GPP & 0.0000 & 0.0000 & 0.0000 & $*$ & $*$ & $*$ \\
$\mathrm{R}_{\text {dark }}$ & 0.0000 & 0.0000 & 0.0005 & $*$ & $*$ & ns \\
NP & 0.0004 & 0.0000 & 0.0000 & $*$ & $*$ & $*$ \\
P:R & 0.0000 & 0.0000 & 0.0001 & $n s$ & $*$ & $*$
\end{tabular}

375

$P: R \quad 0.0000 \quad 0.0000 \quad 0.0001 \quad$ ns * *

\section{Offshore}

\begin{tabular}{cccccc} 
treatment & time & interaction & $\mathrm{E}-\mathrm{C}$ & $\mathrm{N}-\mathrm{C}$ & $\mathrm{E}-\mathrm{N}$ \\
\hline 0.0000 & 0.0000 & 0.0000 & $*$ & $*$ & $*$ \\
0.0000 & 0.0000 & 0.0000 & $*$ & $n s$ & $*$ \\
0.0000 & 0.0000 & 0.0000 & $*$ & $n s$ & $*$ \\
0.7165 & 0.0000 & 0.0496 & $n s$ & $n s$ & $n s$ \\
0.0038 & 0.0000 & 0.0000 & $*$ & $*$ & $n s$
\end{tabular}

Table 5. Output of multifactorial ANOVA on chl a concentrations and metabolic rates for the Lagoon and Offshore experiments, depending on treatment or incubation time. GPP: gross primary production; $\mathrm{R}_{\text {dark }}$ : community respiration in the dark; NP: net production; P:R: production to respiration ratio. $P$-values are given for each variable; non significant differences are highlighted by italics. Significant differences at 95\% confidence levels for treatment comparison (elutriate-control: 

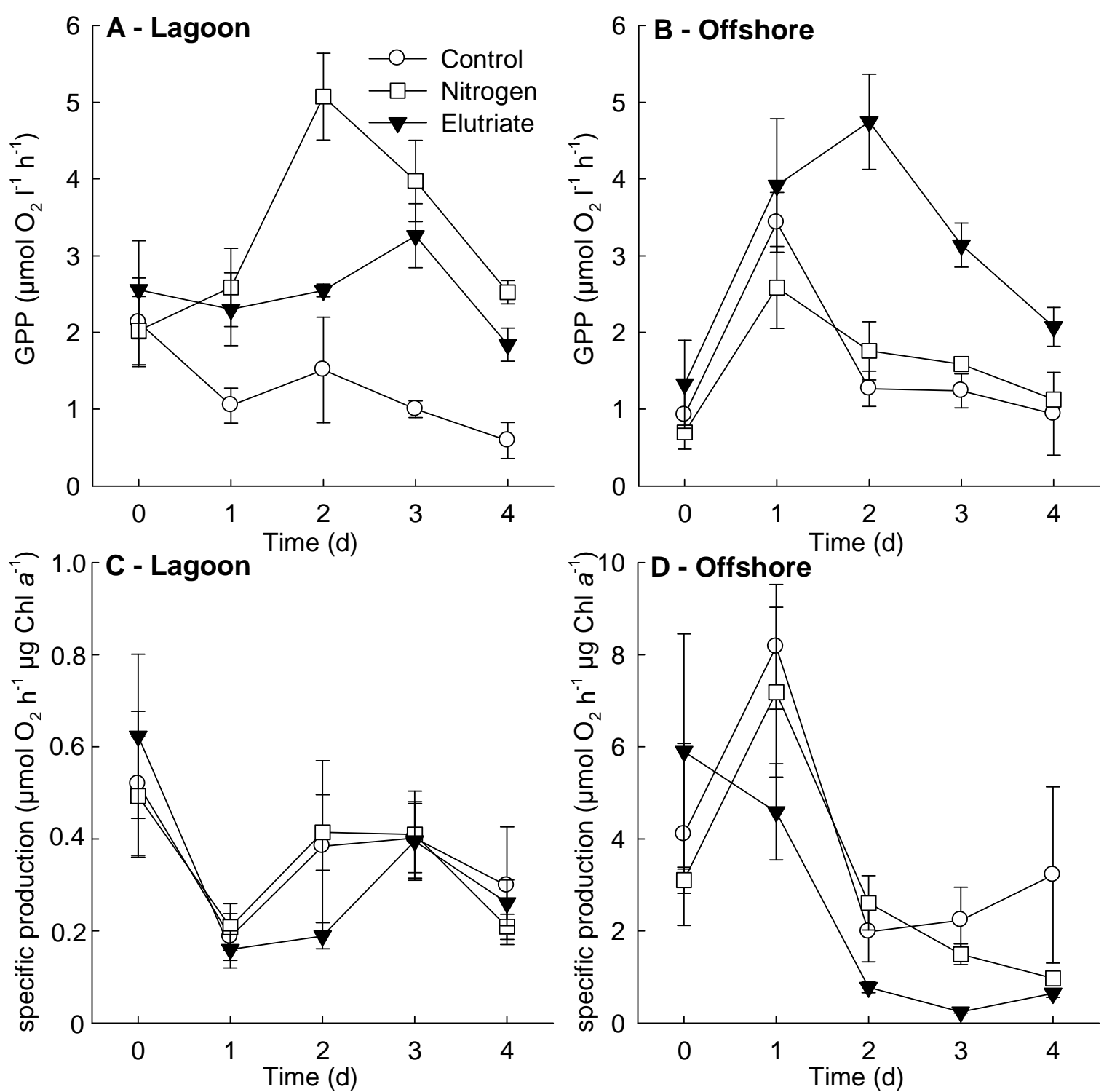

Figure 5. Gross oxygen production rates (GPP) measured in the Lagoon (Fig. 5A) and offshore (5B)

experiment during the incubation, and specific oxygen production per unit of chl $a$ in the same microcosms (Fig. 5C and 5D). Please note the different y scales for 5C and 5D graphs.

From GPP values and chl $a$ concentrations, the specific phytoplankton activity was calculated (specific GPP = GPP / $[\mathrm{chl} a])$. A significant decrease was observed in the oxygen productivity in the lagoon experiment over the first $24 \mathrm{~h}$ with a fall from 0.52 to $0.18 \mu \mathrm{mol} \mathrm{O}_{2} \mathrm{~h}^{-1} \mu \mathrm{g}$ chl $a^{-1}$ in C microcosms, 0.62 to $0.15 \mu \mathrm{mol} \mathrm{O}_{2} \mathrm{~h}^{-1} \mu \mathrm{g} \mathrm{chl} a^{-1}$ in E microcosms and 0.49 to $0.2 \mu \mathrm{mol} \mathrm{O} \mathrm{O}^{-1} \mu \mathrm{g}$ chl $a^{-1}$ in N microcosms

(Fig. 5C). No significant differences arose for specific gross primary production between the three treatments ( $p>0.05)$. GPP increased over the rest of the incubation period and the average specific 
393

394

395

396

397

398

399

400

401

402

403

404

405

406

407

408

409

410

411

412

413

phytoplankton activity was $0.36,0.3$ and $0.34 \mu \mathrm{mol} \mathrm{O}_{2} \mathrm{~h}^{-1} \mu \mathrm{g}$ chl $a^{-1}$ respectively for $\mathrm{C}, \mathrm{E}$ and $\mathrm{N}$ microcosms (Fig. 5C), without any significant differences between the three treatments $(p>0.05)$. The specific phytoplankton activity in the offshore experiment was marked by a significant increase at 24h in $\mathrm{C}$ (from 4.1 to $8.2 \mu \mathrm{mol} \mathrm{O} \mathrm{O}^{-1} \mu \mathrm{g} \mathrm{chl} a^{-1}$ ) and $\mathrm{N}$ (from 3.1 to $7.2 \mu \mathrm{mol} \mathrm{O} \mathrm{O}^{-1} \mu \mathrm{g}$ chl $a^{-1}$ ) microcosms at $24 \mathrm{~h}$ but a decrease in $\mathrm{E}$ (from 6 to $4.5 \mu \mathrm{mol} \mathrm{O} \mathrm{O}^{-1} \mu \mathrm{g}$ chl $a^{-1}$ ). For the remnant of the incubation experiment, specific activities decreased regardless of treatment (Fig. 5D). In a general way, specific activities of communities from the offshore station were one order of magnitude higher than the ones measured for lagoon communities.

The same patterns were observed for dark respiration measurements compare to GPP. In Lagoon experiment, $\mathrm{R}_{\text {dark }}$ increased significantly $(p<0.05)$ in the $\mathrm{E}$ and $\mathrm{N}$ microcosms relative to controls during all the incubation period (Fig. 6A). The average respiration rates measured during the experiment were 1.55; 2.23 and $2.39 \mu \mathrm{mol} \mathrm{O}_{2} \mathrm{I}^{-1} \mathrm{~h}^{-1}$ in the $\mathrm{C}, \mathrm{E}$ and $\mathrm{N}$ microcosms, respectively. Throughout the experiment, the net production did not reach positive values in any of the microcosms. Compared to the lagoon station, the respiration in the station $\mathrm{O}$ was significantly stimulated only in E microcosms (average rate: $2.39 \mu \mathrm{mol} \mathrm{O} \mathrm{O}^{-1} \mathrm{~h}^{-1}$ ) compare to the $\mathrm{C}$ (average rate: $0.87 \mu \mathrm{mol} \mathrm{O} \mathrm{I}^{-1} \mathrm{~h}^{-1}$ ) and $\mathrm{N}$ (average rate: $0.93 \mu \mathrm{mol} \mathrm{O} \mathrm{O}_{2}^{-1} \mathrm{~h}^{-1}$ ) ones (Fig. 6B, Table 5). No significant differences arose between the control and $\mathrm{N}$ microcosms $(\mathrm{p}>0.05)$. In the offshore station, and throughout the experiment, net production was not positive in any of the microcosms, except for a transient state after $24 \mathrm{~h}$ incubation, where net autotrophy was noticed in C and $\mathrm{N}$ microcosms (Fig. 6C). On the contrary, in E microcosms the system appeared heterotrophic throughout the whole incubation time (Fig. 6D, Table 5). 

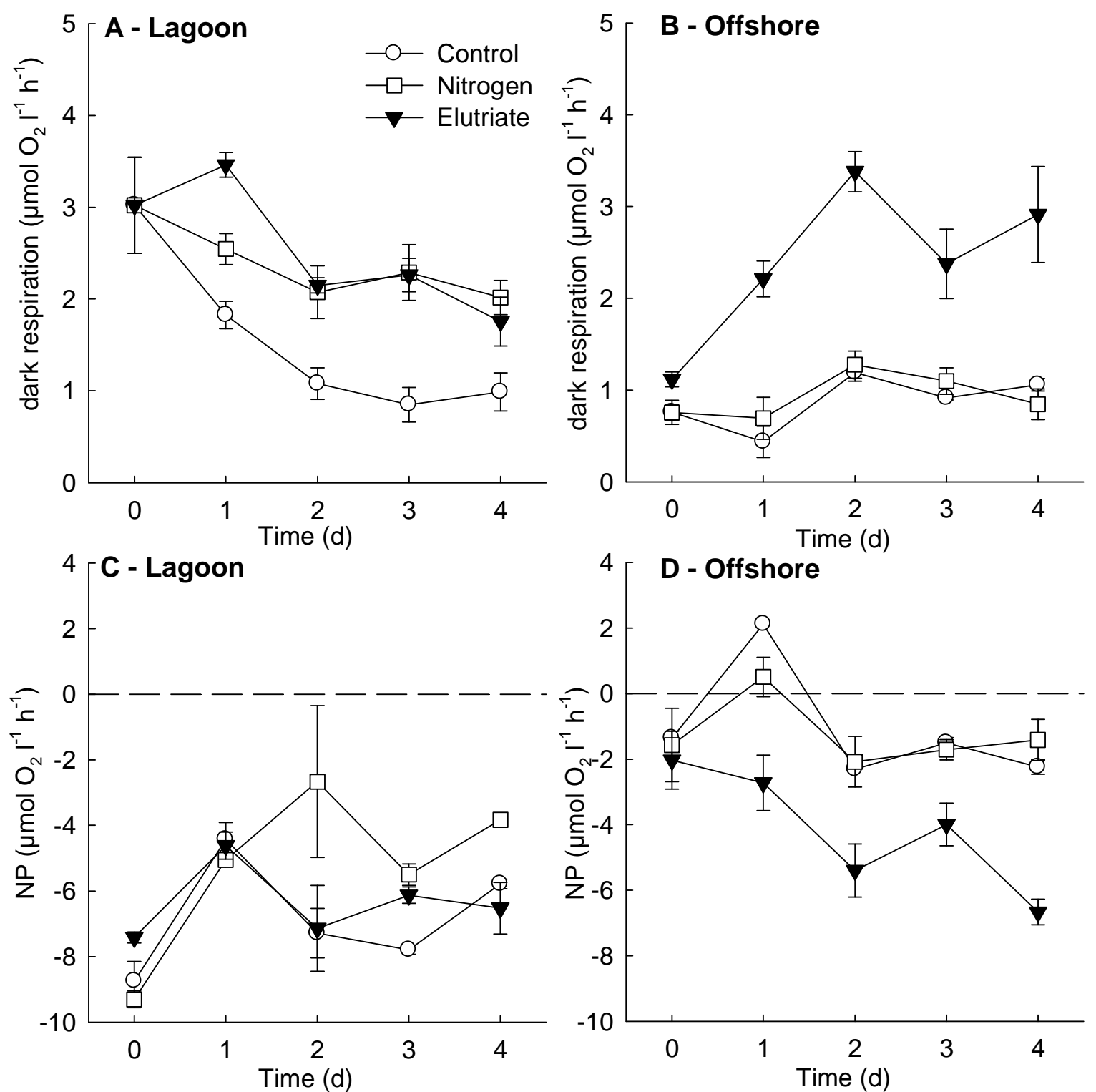

Figure 6. Dark respiration rates measured in the Lagoon (Fig. 6A) and Offshore (6B) experiments during the incubation, and net oxygen production (NP) in the same microcosms (Fig. 6D and 6D). Dashed line figures the exact balance between gross production and respiration (NP $=0$ ).

\section{Discussion}

\subsection{Contaminants and nutrients released from the sediments}

420 Concentrations of PAHs in Thau lagoon sediments found during this study were significant ( $2 \mathrm{PAH} 16=$

$4218.7 \mu \mathrm{g} \mathrm{g}^{-1} \mathrm{dry}$ weight), similar to previous reports from studies in the same area ( $\mathrm{PAH} 16=0.44$ to 7.7

$422 \mu \mathrm{g} \mathrm{g}^{-1}$ dry weight, Léauté, 2008). Sediments from Eaux Blanches bay and Crique de l'Angle creek 
423 (station S and station L respectively in Fig. 1) have been found to be mainly contaminated with PAHs, 424 with total amounts of 8 and $7 \mu \mathrm{g} \mathrm{g}^{-1}$ dry weight, respectively (Léauté, 2008). PAHs concentrations in 425 the sediments of the eastern part of Thau lagoon were similar to those found in other highly contaminated ecosystems, such as in sediments from Ushuaia Bay $\left(7.6 \mu \mathrm{g} \mathrm{g}{ }^{-1}\right.$ dry weight; Massara Paletto et al., 2008), but much higher than those found in Daya Bay (South China) (0.04 to $0.158 \mu \mathrm{g} \mathrm{g}$ Bizerte lagoon (1.49 $\mathrm{gg} \mathrm{g}^{-1}$ dry weight; Lafabrie et al., 2013b) for example. Polychlorobiphenyls (PCBs) were also found in significant levels in sediments, at higher concentrations ( $\Sigma$ PCB7 $=0.059 \mu \mathrm{g} \mathrm{g}^{-1} \mathrm{dry}$ weight) than previously reported in the same area ( $\Sigma \mathrm{PCB} 7=0.0006$ to $0.030 \mu \mathrm{g} \mathrm{g}^{-1} \mathrm{dry}$ weight; Léauté, 2008). Despite these high levels in sediment, the concentrations of all PAHs and PCBs in the elutriate (CW filtered through $0.2 \mu \mathrm{m}$ ) were below detection limits (Table 1).These PAH and PCB contaminants have hydrophobic properties and a strong affinity for particles in the water column (Luellen and Shea, 2002; Tolosa et al., 1995), and may have been removed by filtration together with particulate matter.

The shift from anoxic (sediment in place) to oxic conditions (suspended sediment) may change the partition and speciation of contaminants, particularly adsorbed trace metals prone to solubilization (Petersen et al., 1996). Metals were not measured in the sediment in the present study, but previous published works reported high level of contamination in the Eaux Blanches bay (Kawakami et al., 2008). From the top five centimeters layer of a sediment core sampled in the same location (station 5, Fig. 2 in Kawakami et al., 2008), these authors previously found concentrations of $93 \mu \mathrm{g} \cdot \mathrm{g}^{-1}$ for lead, $2.2 \mu \mathrm{g} \cdot \mathrm{g}^{-1}$ for cadmium, $95.3 \mu \mathrm{g} \cdot \mathrm{g}^{-1}$ for copper, and $29.3 \mu \mathrm{g} \cdot \mathrm{g}^{-1}$ for nickel (sediment dry weight). This could explain the high concentrations of trace metals in the elutriate (Table 1). A similar study performed in Biguglia lagoon (Corsica) also reported low levels of PAHs in total elutriates (although

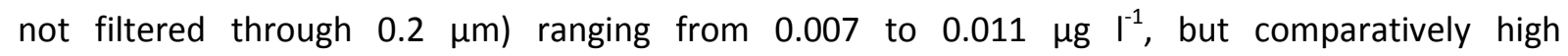
447 concentrations of trace metals (ranging from 0.07 to $27 \mu \mathrm{g} \mathrm{I}^{-1}$ ) (Lafabrie et al., 2013a). Results 
presented here show that the resuspension of sediments resulted mostly in the release of metal

449 contaminants and nutrients, especially ammonium (20 $\mu \mathrm{M})$, in dissolved form in the water column.

450 Sediment quality guidelines and ecological safety values for contaminants in marine waters are still

451 debated, but several studies attempted to summarize toxicity values for individual chemicals in the

452 context of risk assessment. The measured concentration of chemicals and metals in the sediment

453 and elutriates used in the present study were compared to known concentrations with predicted

454 effects on biota (Table 6). Long et al. (1995) defined two threshold levels as Effect Range Low (ERL)

455 and Effect Range Median (ERM) derived from effect data distribution on sediment, namely the $10^{\text {th }}$

456 and $50^{\text {th }}$ percentile respectively, whereas harmful concentration for $5 \%$ of the species (HC5) in sea

457 water were derived from species-sensitivity distribution curves (Ben Othman et al., 2012, Wang et

458 al., 2014, Wheeler et al., 2002). For all the values but one measured in the present study,

459 contaminant concentrations in sediment were between ERL and ERM, whereas contaminated water

460 values were always below documented HC5. Only naphthalene concentration in sediment was below

461 ERL (Table 6).

\begin{tabular}{|c|c|c|c|c|c|}
\hline & \multicolumn{3}{|c|}{$\begin{array}{c}\text { in sediment } \\
\left(\mathrm{ppb}=\mu \mathrm{g} \mathrm{kg}^{-1} \text { dry weight }\right)\end{array}$} & \multicolumn{2}{|c|}{$\begin{array}{l}\text { in contaminated water } \\
\left(\mu \mathrm{g} \mathrm{I}^{-1}\right)\end{array}$} \\
\hline organics & measured $^{*}$ & $E R L^{\S}$ & $\mathrm{ERM}^{\S}$ & measured $^{*}$ & $\mathrm{HC} 5$ \\
\hline Anthracene & 220 & 85.3 & 1100 & bdl & \\
\hline Benzo(a)anthracene & 780 & 261 & 1600 & bdl & \\
\hline Benzo(a)pyrene & 870 & 430 & 1600 & bdl & $0.011^{\&}$ \\
\hline Chrysene & 720 & 384 & 2800 & bdl & \\
\hline Fluoranthene & 1700 & 600 & 5100 & bdl & $21^{!}$ \\
\hline Naphthalene & 30 & 160 & 2100 & bdl & \\
\hline Phenanthrene & 740 & 240 & 1500 & bdl & $2.33^{\&}$ \\
\hline Pyrene & 1240 & 665 & 2600 & bdl & $1.09^{\&}$ \\
\hline \multirow[t]{2}{*}{$\Sigma_{\mathrm{PCB}}$ congeners } & 59 & 22.7 & 180 & bdl & \\
\hline & \multicolumn{3}{|c|}{ (ppm $=\mu g^{-1}$ dry weight) } & \multicolumn{2}{|c|}{$\left(\mu g I^{-1}\right)$} \\
\hline metals & measured $^{\#}$ & $\mathrm{ERL}^{\S}$ & $\mathrm{ERM}^{\S}$ & measured $^{*}$ & $\mathrm{HC5}^{£}$ \\
\hline Lead & 93 & 46.3 & 218 & 0.088 & 238.2 \\
\hline Cadmium & 2.2 & 1.2 & 9.6 & 0.021 & 8.22 \\
\hline Copper & 95.3 & 34 & 270 & 2.49 & 22.7 \\
\hline Nickel & 29.3 & 20.9 & 51.6 & 0.62 & 597.7 \\
\hline
\end{tabular}

Table 6. Comparison of sediment and elutriate contamination levels (*: this study) to documented sediment quality guidelines (ERL and ERM) and predicted ecological effects (HC5) for marine waters.

464 §: data from Long et al., 1995; \#: data from Kawakami et al., 2008; \&: data from Wang et al., 2014; !:

465 data from Ben Othman et al., 2012; f: data from Wheeler et al., 2002. bdl: below detection limit. 


\subsection{Effect of contaminated sediment elutriate on phytoplankton growth}

Both $\mathrm{E}$ and $\mathrm{N}$ treatments increased phytoplankton growth in lagoon station, resulting in final $\mathrm{chl} a$ concentrations that were two and three times higher in the $\mathrm{E}$ and $\mathrm{N}$ microcosms, respectively, than in the control microcosms. By comparison, in the offshore station, supplementation by ammonium ( $\mathrm{N}$ microcosms) did not induce increase ( $p>0.05$ ) in chlorophyll $a$ compared to the control (Fig. 2B), whereas $\mathrm{E}$ treatment resulted in a ten times increase compare to $\mathrm{C}$ and $\mathrm{N}$ treatments. These results suggest that the nutrients counteract the possible harmful effects of contaminants on phytoplankton and that nitrogen in the form of $\mathrm{NH}_{4}{ }^{+}$was likely to be the most limiting element for the phytoplankton in the lagoon station. In such a situation, nitrogen alone limits the growth of phytoplankton and elutriate addition can release this limitation. In the offshore community, nitrogen addition alone did not trigger phytoplankton growth, whereas an unknown limiting factor was made available by elutriate addition.

Such phytoplankton growth stimulation was also observed for example after a wind-mixing event in a shallow subtropical bay in Florida (Lawrence et al., 2004) and the increases in $\mathrm{NH}_{4}{ }^{+}$and $\mathrm{PO}_{4}{ }^{3-}$ concentrations in the water column were identified as the main causes of this effect. Lafabrie et al. (2013b) showed that both elutriate-contaminated and nutrient enriched water increased phytoplankton growth compared to the control in an experiment performed in the Bizerte Lagoon (Tunisia). Other experiments by the same research group in the Biguglia lagoon (Corsica) suggest that brief sediment resuspension events strongly stimulate growth of phytoplankton communities (Lafabrie et al., 2013a), even when sediments are contaminated by toxic chemicals. By contrast, other studies have reported a decrease in the total phytoplankton biomass after exposure to a combination of contaminants (mix of trace elements) and nutrients (e.g., Riedel et al., 2003). The responses of phytoplankton to a combination of contaminants and nutrients may, therefore, depend on threshold levels above which the contaminants become toxic.

There may be other mechanisms that stimulate phytoplankton growth in the present study. The $E$ microcosms were slightly enriched with metallic micronutrients, such as nickel and zinc (Table 1) 
492

493

494

495

496

497

498

499

500

501

502

503

504

505

506

507

508

509

510

511

512

513

514

515

516

517

which are known to be essential for cell metabolism. These metals are involved in the stabilization of protein structure and also facilitate transfer reactions and/or catalysis of the enzymatic reactions (Torres et al., 2008). For example, Zn plays a key role in the photosynthetic electron transport between the thylakoids (Raven et al., 1999). Molybdenum (which was the most abundant trace metal in the $\mathrm{E}$ microcosms) $\mathrm{Mn}$ and $\mathrm{Fe}$ are involved as enzyme cofactors in respiration, photosynthesis and nitrogen metabolisms and may be limiting for natural phytoplankton populations in situ (Boyd et al., 1996; Howarth and Cole 1985). Essential metal-micronutrients (Zn, Mo, Mn and Fe) which were abundant in the elutriate could therefore favor algal growth provided that their concentrations do not exceed the tolerance thresholds of organisms. It has been shown that some dissolved metals ( $\mathrm{Co}, \mathrm{Ni}$ and $\mathrm{Zn}$ ) are able to increase the chlorophyll biomass, but they may also be harmful at higher concentrations (Chakraborty et al., 2010).

\subsection{Effect of contaminated sediment elutriate on phytoplankton structure}

The results of the present study in lagoon station showed that diatoms were stimulated in the $\mathrm{N}$ microcosms compared to other treatments. This appeared contradictory with Lafabrie et al. (2013a) who showed that the high $\mathrm{NH}_{4}{ }^{+}$levels $(100 \mu \mathrm{M})$ in their experiment resulted in a decrease in diatom abundance. Actually, this concentration was 5 times higher than the $\mathrm{NH}_{4}{ }^{+}$levels $(20 \mu \mathrm{M})$ used in the present study, and can be explained by a potential toxicity of ammonium at high concentrations. In the offshore station, diatoms were stimulated in the E microcosms compare to other treatments. Chikhaoui et al. (2008) highlighted the fact that dissolved silicate can be a limiting factor and an essential element to the growth and metabolism of diatoms communities, even in coastal, nutrientrich waters. Diatoms in the E microcosms were represented exclusively by potentially toxic Pseudonitzschia species in both experiments (inoculum from lagoon and offshore stations). This genus has been shown to produce domoic acid, an amnesic shellfish toxin, which is able to chelate various metals (such as Fe and $\mathrm{Cu}$ ) and, therefore, can counteract the toxicity of these pollutants (Lelong et al., 2012; Rue and Bruland, 2001). It has also been reported that some Pseudo-nitzschia species (P. australis and $P$. multiseries) withstand toxic concentrations of $\mathrm{Cu}$ by increasing domoic acid 
518 production (Ladizinsky, 2003; Maldonado et al., 2002). This could suggest that the dominance of

519 Pseudo-nitzschia in the E microcosms in the two stations, enriched in trace metals from sediment,

520 may be related to their ability to produce domoic acid. This makes them more resistant to metal

521 toxicity than other species that do not have this ability, such as Nitzschia longissima in lagoon station,

522 which disappeared from the E microcosms, and the decrease of the contribution of Chaetoceros spp.

523 in offshore station, suggesting that the these species were sensitive to dissolved trace metals.

524 An increase in the cyanobacteria biomass was observed in lagoon station in the ammonium enriched

525 microcosms (N microcosms). Such a pattern was also reported by Fouilland et al. (2012), concluding

526 that inorganic nitrogen limited the growth of prokaryotic picophytoplankton in Thau lagoon. More

527 generally, cyanobacteria are often considered as more tolerant to chemicals, such as reported for

528 example in the study of Stachowski-Haberkorn et al. (2009), after exposing marine phytoplankton to

529 a fungicide (Opus at $100 \mu \mathrm{g}^{-1}$ ) which resulted in an increase in Synechococcus population density.

530 Regarding the dinoflagellates group, the persistence of Alexandrium sp. and relatively high

531 abundance in the $\mathrm{E}$ microcosms (with high level of heavy metals) in the lagoon experiment suggests a

532 relative tolerance of this species to metals. The close relative Alexandrium catenella was shown to be

533 able to resist to Cu toxicity by increasing dissolved organic carbon (DOC) release (Herzi et al., 2013).

534 For dinoflagellates from offshore station, many species in $\mathrm{E}$ and $\mathrm{N}$ microcosms were depauperate

535 compare to the control microcosms. These species were Scrippsiella sp.; Prorocentrum sp. and

536 Prorocentrum minimum, appearing therefore not tolerant to the sediment elutriate.

537 Correspondence analysis highlighted the fact that treatments effects were more pronounced in

538 offshore station compared to lagoon station (Fig. 5), and demonstrated a wide divergence between

539 the initial sample and the three treatments $\mathrm{C}, \mathrm{N}$ and $\mathrm{E}$ microcosms in offshore station. This suggests

540 that phytoplankton sampled from offshore station were more sensitive to the sediment elutriate

541 effects and to the added ammonia compared to the phytoplankton from lagoon station. This can be

542 supported by the observed changes in Shannon index $H$ values. At the end of incubations, the

543 phytoplankton diversity in lagoon station did not differ in the $\mathrm{E}$ and $\mathrm{N}$ treatments compared to the 
544 control $\left(H\right.$ index: $1.7 \pm 0.03 ; 1.55 \pm 0.02$ and $1.6 \pm 0.01$ bits $^{-1}$ ind $^{-1}$, respectively in $\mathrm{C}$, $\mathrm{E}$ and $\mathrm{N}$

545 microcosms) whereas in offshore station the diversity in $C$ microcosms $\left(1.41 \pm 0.04\right.$ bits ind $\left.^{-1}\right)$ was

546 significantly higher than in $\mathrm{E}\left(1.32 \pm 0.002\right.$ bits ind $\left.^{-1}\right)$ and $\mathrm{N}$ microcosms $\left(1.19 \pm 0.03\right.$ bits ind $\left.^{-1}\right)$.

\subsection{Effect of contaminated sediment elutriate on community production and respiration}

548

549

550

551

552

553

554

555

556

557

558

559

560

561

562

563

564

565

566

567

568

569

In lagoon experiment, community respiration followed the same trend as phytoplankton biomass. Actually, the $R_{\text {dark }}$ increased 3 times in $N$ and $E$ microcosms compared to the control $(P<0.05)$. For the offshore experiment, only $E$ treatment resulted in an up to 3-fold increase in dark respiration compared to control microcosms. In this last experiment, $\mathrm{R}$ dark did not change compared to the control $(P>0.05)$ under $N$ treatment. This suggests that the respiration in lagoon station was limited by nitrogen, whereas this element was not a limiting factor for respiratory activity at offshore station.

The specific phytoplankton activity (GPP:chl $a$ ) decreased significantly in the control and both treatments ( $\mathrm{N}$ and $\mathrm{E}$ microcosms) during all the incubation time in lagoon station. Almost the same pattern was observed in the three microcosms treatments in offshore station but, only after $24 \mathrm{~h}$, a transient increase of GPP:chl $a$ was noticed only in C and N treatments compared to $\mathrm{E}$ ones. The studied phytoplankton communities in $\mathrm{N}$ and $\mathrm{C}$ microcosms appeared physiologically more efficient than in $\mathrm{E}$ microcosms after $24 \mathrm{~h}$ incubation in offshore station. Increase in the specific phytoplankton activity, together with slight phytoplankton community structure changes, have been previously reported in a mesocosm experiment for communities exposed to a mix of nutrients with an organic contaminant (pyrene; Hjorth et al., 2008).

The net production gives information on the "trophic state" of a system, currently linked to the production:respiration ratio; $P: R>1$ indicates a net autotrophy state, whereas $P: R<1$ indicates a net heterotrophy state (Dodds and Cole, 2007). In lagoon station, net production was always negative, highlighting the fact that the three microcosms $\mathrm{C}, \mathrm{N}$ and $\mathrm{E}$ were net heterotrophic during all the incubation time. The systems were also heterotrophic in the offshore station in $\mathrm{E}, \mathrm{N}$ and $\mathrm{C}$ microcosms but for this experiment a transient state appeared for only $\mathrm{C}$ and $\mathrm{N}$ microcosms, during 
which the plankton communities were net autotrophic. Previous field-based studies also highlighted the drift of planktonic communities' metabolism towards heterotrophy shortly after sediment resuspension events (Cotner et al., 2000; Lawrence et al., 2004). Similarly, laboratory experiments showed a reduction of the $P: R$ ratio after exposure to trace metal, reduction of the $P: R$ ratio that resulted in a bacterially dominated heterotrophic system (Nayar et al., 2004; Rochelle-Newall et al., 2008).

\section{Conclusion}

This ecotoxicological experiment, conducted on natural phytoplankton sampled from the Thau lagoon and Mediterranean offshore waters, showed that elutriate prepared from sediments stimulated phytoplankton growth despite significant contamination by potentially toxic chemicals. Sediments involved in exposure experiment were considered as significantly contaminated by metals and organics based on quality assessment thresholds. For both phytoplankton communities, significant increases in phytoplankton biomass and cell abundance were observed after elutriate addition. For the lagoon station, the stimulatory effect of elutriate was similar to that of adding $\mathrm{NH}_{4}{ }^{+}$ alone, without any toxic chemical. It is, therefore, likely that the nutrient present in elutriate (especially nitrogen) caused the proliferation of primary producers. On the other hand, the phytoplankton community from the offshore reference station was clearly beneficial from elutriate addition based on observed growth, since nitrogen alone did not promote community proliferation. This may mask the possible harmful effects of contaminants, making it difficult to detect them. On the contrary, the community in the reference station was not limited by the $\mathrm{NH}_{4}{ }^{+}$addition.

The elutriate used in the present study was particularly contaminated with dissolved metals, some of these known to be toxic to phytoplankton $(\mathrm{Cd}, \mathrm{Pb})$, while others $(\mathrm{Zn}, \mathrm{Mo}, \mathrm{Mn}, \mathrm{Fe})$ may be essential for cellular metabolism at low concentrations. As a consequence, the presence of essential trace metals in sediment elutriate could be a possible cause of increased phytoplankton growth, provided that their levels remain below the tolerance threshold of these organisms. 
595 Contamination also changed the community structure of Thau and offshore phytoplankton. It 596 appears that adding sediment elutriate was most beneficial to species that were potentially toxic.

597 The most significant change concerned the pronounced proliferation of potentially toxic diatoms 598 (Pseudo-nitzschia sp.) and dinoflagellates (Alexandrium sp. in lagoon station and Gymnodinium sp. in 599 offshore station) after the addition of sediment elutriate. Hence, it could be suggested that these 600 microalgae have defense mechanisms (synthesis of toxin excretion of dissolved organic matter, for

601

602

603

604

605

606

607

608

609

610

611

612

613

614

615

616

example) making them more resistant to chemical contamination (especially metallic in the present study). For the phytoplankton in offshore, and in the very short term, the system shifted to autotrophy after sediment elutriate addition compared to the control. By contrast, the lagoon community metabolic balance remained net heterotrophic during all the experiments and for all treatments. Apart from changes in community composition, such a transient shift in the global metabolic balance of plankton community should be considered when addressing the ecological impact of contaminated sediment in coastal marine ecosystems. The present results showed also that the treatments effects were more pronounced in offshore station compared to the lagoon station, suggesting that phytoplankton in offshore station were more sensitive to both elutriate and added ammonia compared to the phytoplankton in lagoon station. Future progress in the risk assessment of contaminated sediment for planktonic organisms will benefit from enhanced knowledge on toxicity of pure chemicals to marine microorganisms (e.g. Ben Othman et al., 2012) together with community level evaluation of toxic chemical cocktails taking into consideration the stimulating effects of co-released nutrients (Pringault et al., 2016). These approaches will help in discriminating true toxic effects, linked to toxic contamination, from nutrient enrichment effects that accompany sediment resuspension events.

\section{Acknowledgements}

This work was partly funded by the BPi France agency and the Région Languedoc-Roussillon, program ECODREDGE-MED grant number F11060012J. H.B.O. benefited from a PhD grant by the French Institute of Research for Development (IRD). Claire Carré is warmly acknowledged for her help during microscopic 
phytoplankton determination. The Ecole des Mines d'Alès (Dr. Catherine Gonzalez) and the UMR 5569

HydroSciences (Dr. Françoise Elbaz-Poulichet) provided the analytical facilities for chemical contaminants determination. Experimental work benefited from the logistical and technical support of the MEDIMEER experimental platform (OSU OREME, Sète). English text was edited by Tony Tebby. Anonymous referees are warmly acknowledged for triggering substantial enhancements on the early version of this manuscript.

\section{References}

Anschutz, P., Chaillou, G., Lecroart, P., 2007. Phosphorus diagenesis in sediment of the Thau lagoon. Estuar. Coastal Shelf Sci. 72, 447-456.

Ben Othman, H., Leboulanger, C., Le Floc'h, E., Hadj Mabrouk, H., Sakka Hlaili, A., 2012. Toxicity of benz(a)anthracene and fluoranthene to marine phytoplankton in culture: does cell size really matter? J. Hazardous Mater. 243, 204-211.

Birch, G., O'Hea, L., 2007. The chemistry of suspended particulate material in a highly contaminated embayment of Port Jackson (Australia) under quiescent, high-wind and heavy-rainfall conditions. Environ. Geol. 53, 501-516.

Bonnet, C., Babut, M., Férard, J.F., Martel, L., Garric, J., 2000. Assessing the potential toxicity of resuspended sediment. Environ. Toxicol. Chem. 19, 1290-1296.

Boyd, P.W., Muggli, D.L., Varela, D.E., Golblatt, R.H., Chretien, R., Orians, K.J., Harrison, P.J., 1996. In vitro iron enrichments in the NE subarctic Pacific. Mar. Ecol. Progr. Ser. 136, 179-193.

Budzinski, H., Jones, I., Bellocq, J., Piérard, C., Garrigues, P., 1997. Evaluation of sediment contamination by polycyclic aromatic hydrocarbons in the Gironde estuary. Mar. Chem. 58, 85-97.

Burton, G.A., Johnston, E.L., 2010. Assessing contaminated sediments in the context of multiple stressors. Environ. Toxicol. Chem. 29, 2625-2643.

Cantwell, M., Burgess, R., Kester, D., 2002. Release and phase partitioning of metals from anoxic estuarine sediments during periods of simulated resuspension. Environ. Sci. Technol. 36, 5328-5334.

Castro-Jiménez, J., Deviller, G., Ghiani, M., Loos, R., Mariani, G., Skejo, H., Umlauf, G., Wollgast, J., Laugier, T., Héas-Moisan, K. , Léauté, F., Munschy, C., Tixier, C., Tronczynski, J., 2008. PCDD/F and PCB multi-media ambient concentrations, congener patterns and occurrence in a Mediterranean coastal lagoon (Etang de Thau, France). Environ. Poll. 156, 123-135.

Chakraborty, P., Babu, P.V.R., Acharyya, T., Bandyopadhyay, D., 2010. Stress and toxicity of biologically important transition metals (Co, Ni, $\mathrm{Cu}$ and $\mathrm{Zn}$ ) on phytoplankton in a tropical freshwater system: An investigation with pigment analysis by HPLC. Chemosphere 80, 548-553.

Chikhaoui, M.A., Sakka Hlaili, A., Hadj Mabrouk, H., 2008. Seasonal phytoplankton responses to N:Si:P enrichment ratio in the Bizerte Lagoon (Southwestern Mediterranean). Comptes Rendus Biologies 331, 389-408.

Cornelissen, G., Arp, H., Pettersen, A., Hauge, A., Breedveld, G., 2008. Assessing PAH and PCB emissions from the relocation of harbour sediments using equilibrium passive samplers. Chemosphere 72, 1581-1587.

Cotner, J.B, Johengen, T.H., Biddanda, B.A., 2000. Intense winter heterotrophic production stimulated by benthic resuspension. Limnol. Oceanogr. 45, 1672-1676.

Crain, C.M., Kroeker, K., Halpern, B.S., 2008. Interactive and cumulative effects of multiple human stressors in marine systems. Ecol. Lett. 11, 1304-1315.

De Hoop, L., De Troch, M., Hendricks, A.J., De Laender, F., 2013. Modeling toxic stress by atrazine in a marine consumer-resource system. Environ. Toxicol. Chem. 32, 1088-1095.

de la Broise, D., Palenik, B., 2007. Immersed in situ microcosms: A tool for the assessment of pollution impact on phytoplankton. J. Exp. Mar. Biol. Ecol. 341, 274-281.

Dodds, W.K., Cole, J.J., 2007. Expanding the concept of trophic state in aquatic ecosystems: It's not just the autotrophs. Aquat. Sci. 69, 427-439.

Edge, K.J., Dafforn, K.A., Simpson, S.L., Ringwood, A.H., Johnston, E.L., 2015. Resuspended contaminated sediments cause sublethal stress to oysters: a biomarker differentiates total suspended solids and contaminant effects. Environ. Toxicol. Chem. 34, 1345-1353.

Edge, K.J., Johnston, E.L., Dafforn, K.A., Simpson, S.L., Tutti, T., Bannister, R.J., 2016. Sub-lethal effects of waterbased drilling muds on the deep-water sponge Geodia barretti. Environ. Poll. 212, 525-534. 
Field, C.B., Behrenfeld, M.J., Randerson, J.T., Falkowski, P.G. 1998. Primary production of the biosphere: integrating terrestrial and oceanic components. Science. 281, 237-240.

Fouilland, E., Trottet, A., Bancon-Montigny, C., Bouvy, M., Le Floc'h, E., Gonzalez, J.L., Hatey, E., Mas, S., Mostajir, B., Nouguier, J., Pecqueur, D., Rochelle-Newall, E., Rodier, C., Roques, C., Salles, C., Tournoud, M.G., Vidussi, F., 2012. Impact of a river flash flood on microbial carbon and nitrogen production in a Mediterranean Lagoon (Thau Lagoon, France). Estuar. Coastal Shelf Sci. 113, 192-204.

Gilbert, F., Souchu, P., Bianchi, M., Bonin, P., 1997. Influence of shellfish farming activities on nitrification nitrate reduction to ammonium and denitrification at the water -sediment interface of the Thau lagoon France. Mar. Ecol. Progr. Ser. 151, 143-153.

Hammer, $\varnothing$., Harper, D.A.T., 2001. PAST: paleontological statistics software package for education and data analysis. Paleontologica Electronica 41, 9pp.

Herzi, F., Jean, N., Zhao, H.Y., Mounier, S., Hadj Mabrouk, H., Sakka Hlaili, A., 2013. Copper and cadmium effects on growth and extracellular exudation of the marine toxic dinoflagellate Alexandrium catenella: 3D-fluorescence spectroscopy approach. Chemosphere 93, 1230-1239.

Hill, N., King, C., Perrett, L., Johnston, E., 2009. Contaminated suspended sediments toxic to an Antarctic filter feeder: aqueous- and particulate-phase effects. Environ. Toxicol. Chem. 28, 409-417.

Hjorth, M., Forbes, V.E., Dahllof, I., 2008. Plankton stress responses from PAH exposure and nutrient enrichment. Mar. Ecol. Progr. Ser. 363, 121-130.

Holmes, M.R., Aminot, A., Kérouel, R., Hooker, B.A., Peterson, B.J., 1999. A simple and precise method for measuring ammonium in marine and freshwater ecosystems. Can. J. Fish. Aquat. Sci. 56, 1801-1808.

Howarth, R.W., Cole, J.J., 1985. Molybdenum availability, nitrogen limitation, and phytoplankton growth in natural waters. Science 229, 653-655.

Jonas, P., Millward, G., 2010. Metals and nutrients in the Severn Estuary and Bristol Channel: contemporary inputs and distributions. Mar. Poll. Bull. 61, 52-67.

Jones-Lee, A., Lee, G., 2005. Role of iron chemistry in controlling the release of pollutants from resuspended sediments. Remediation 16, 33-41.

Josefsson, S., Leonardsson, K., Gunnarsson, J., Wiberg, K., 2010. Bioturbation-driven release of buried PCBs and PBDEs from different depths in contaminated sediments. Environ. Sci. Technol. 44, 7456-7464.

Kalnejais, L., Martin, W., Bothner, M., 2010. The release of dissolved nutrients and metals from coastal sediments due to resuspension. Mar. Chem. 121, 224-235.

Kawakami, S.K., Seidel, J.L., Elbaz-Poulichet, F., Achterberg, E.P., 2008. Trace-metal biogeochemistry in the Mediterranean Thau Lagoon, a shellfish farming area. J. Coastal Res. 24, 194-202.

Laabir, M., Jauzein, C., Genovesi, B., Masseret, E., Grzebyk, D., Cecchi, P., Vaquer, A., Perrin, Y., Collos, Y., 2011. Influence of temperature, salinity and irradiance on the growth and cell yield of the harmful red tide dinoflagellate Alexandrium catenella colonizing Mediterranean waters. J. Plankton Res. 33, 1550-1563.

Ladizinsky, N., 2003. The influence of dissolved copper on the production of domoic acid by Pseudo-nitzschia species in Monterey Bay, California: laboratory experiments and field observations. California State University. Monterey Bay, CA, USA, 68 p.

Lafabrie, C., Garrido, M., Leboulanger, C., Cecchi, P., Grégori, G., Pasqualini, V., Pringault, O., 2013a. Impact of contaminated-sediment resuspension on phytoplankton in the Biguglia lagoon (Corsica, Mediterranean Sea). Estuar. Coastal Shelf Sci. 130, 70-80.

Lafabrie, C., Sakka Hlaili, A., Leboulanger, C., Tarhouni, I., Ben Othman, H., Mzoughi, N., Chouba, L., Pringault, O., 2013b. Contaminated sediment resuspension induces shifts in phytoplankton structure and function in a eutrophic Mediterranean lagoon. Knowledge Managt. Aquatic Ecosyst. 410, 05. DOI: $10.1051 / \mathrm{kmae} / 2013080$

Lawrence, D., Dagg, M.J., Liu, H.B., Cummings, S.R., Ortner, P.B., Kelble, C., 2004. Wind events and benthicpelagic coupling in a shallow subtropical bay in Florida. Mar. Ecol. Progr. Ser. 266, 1-13.

Léaute, F., 2008. Biogéochimie des contaminants organiques HAP, PCB et pesticides organochlorés dans les sédiments de l'étang de Thau. [Biogeochemistry of organic contaminants $P A H, P C B$ and organochlorine pesticides in Thau lagoon sediments]. PhD Thesis, 255 pp., full text: http://tel.archivesouvertes.fr/docs/00/44/95/16/ PDF/THESE F LEAUTE.pdf

Lelong, A., Jolley, F., Soudant, P., Hégaret, H., 2012. Impact of copper exposure on Pseudo-nitzschia spp. physiology and domoic acid production. Aquat. Toxicol. 118, 37-47.

Levin, L.A., Boesch, D.F., Covich, A., Dahm, C., Erseus, C., Ewel, K.C., Kneib, R.T., Moldenke, A., Palmer, M.A., Snelgrove, P., Strayer, D., Weslawski, J.M., 2001. The function of marine critical transition zones and the importance of sediment biodiversity. Ecosystems 4, 430-451. 
Long, E.R., MacDonald, D.D., Smith, S.L., Calder, F.D., 1995. Incidence of adverse biological effects within ranges of chemical concentrations in marine and estuarine sediments. Environ. Managt. 19, 81-97.

Luellen, D.R., Shea, D., 2002. Calibration and field verification of semipermeable membrane devices for measuring polycyclic aromatic hydrocarbons in water. Environ. Sci. Technol. 36, 1791-1797.

Maldonado, M.T., Hughes, M.P., Rue, E.L., Wells, M.L., 2002. The effect of Fe and Cu on growth and domoic acid production by Pseudo-nitzschia multiseries and Pseudo-nitzschia australis. Limnol. Oceanogr. 47, 515-526.

Massara Paletto, V., Commendatore, M.G., Esteves, J.L., 2008. Hydrocarbon levels in sediments and bivalve mollusks from Bahía Nueva. (Patagonia, Argentina): An assessment of probable origin and bioaccumulation factors. Mar. Poll. Bull. 56, 2082-2105.

Nayar, S., Goh, B.P., Chou, L.M., 2004. Environmental impact of heavy metals from dredged and resuspended sediments on phytoplankton and bacteria assessed in in situ mesocosms. Ecotox. Environ. Safety 59, 349-369.

Neveux, J., Lantoine, F., 1993. Spectrofluorometric assay of chlorophylls and phaeopigments using the least squares approximation technique. Deep-Sea Res. Part I 40, 1747-1765.

Novarino, G., Oliva, E., Pérez-Uz, B., 2002. Nanoplankton protists from the Western Mediterranean Sea. I. Occurrence, ultrastructure, taxonomy, and ecological role of the mixotrophic flagellate Ollicola vangoorii (Chrysomonadidae = Chrysophyceae p.p.). Scientia Marina 66, 233-247.

Petersen, W., Hong, J., Willamowski, C., Wallmann, K., 1996. The influence of diagenetic processes on the exchange of trace contaminants at the sediment-water interface. Arch. Hydrobiol. SI Advanc. Limnol. 47: 295-305.

Pringault, O., Lafabrie, C., Avezac, M., Bancon-Montigny, C., Carré, C., Chalghaf, M., Delpoux, S., Duvivier, A., Elbaz-Poulichet, F., Gonzalez, C., Got, P., Leboulanger, C., Spinelli, S., Sakka Hlaili, A., Bouvy, M., 2016. Consequences of contaminant mixture on the dynamics and functional diversity of bacterioplankton in a southwestern Mediterranean coastal ecosystem. Chemosphere 144, 1060-1073.

Pringault, O., Tassas, V., Rochelle-Newall, E., 2007. Consequences of respiration in the light on the determination of production in pelagic systems. Biogeosciences 4, 105-114.

Raven, J.A., Evans, M.C.W., Korb, R.E., 1999. The role of trace metals in photosynthetic electron transport in $\mathrm{O}_{2}$ evolving organisms. Photosynth. Res. 60, 111-149.

Riedel, G.F., Sanders, J.G., Breitburg, D.L., 2003. Seasonal variability in response of estuarine phytoplankton communities to stress: Linkages between toxic trace elements and nutrient enrichment. Estuaries 26, 323-338.

Rigollet, V., Sfriso, A., Marcomini, M., De Casabianca, M.L., 2004. Seasonal evolution of heavy metal concentrations in the surface sediments of two Mediterranean Zostera marina $\mathrm{L}$. beds at Thau lagoon (France) and Venice lagoon (Italy). Biores. Technol. 95, 159-167.

Roberts, D.A., 2012. Causes and ecological effects of resuspended contaminated sediments (RCS) in marine environments. Environ. Internat. 40, 230-243.

Rochelle-Newall, E.J., Delesalle, B., Mari, X., Rouchon, C., Torreton, J.P., Pringault, O., 2008. Zinc induces shifts in microbial carbon flux in tropical coastal environments. Aquatic Microb. Ecol. 52, 57-68.

Rue, E., Bruland, K., 2001. Domoic acid binds iron and copper: a possible role for the toxin produced by the marine diatom Pseudo-nitzschia. Mar. Chem. 76, 127-134.

Stachowski-Haberkorn, S., Quiniou, L., Beker, B., Haberkorn, H., Marie, D., de la Broise, D., 2009. Comparative study of three analysis methods (TGGE, flow cytometry and HPLC) for xenobiotic impact assessment on phytoplankton communities. Ecotoxicology 18, 364-376.

Tolhurst, L., Barry, J., Dyer, R., Thomas, K., 2007. The effect of resuspending sediment contaminated with antifouling paint particles containing Irgarol 1051 on the marine macrophyte Ulva intestinalis. Chemosphere 68, 1519-1524.

Tolosa, I., Bayona, J.M., Albaigés, J., 1995. Spatio temporal distribution, fluxes, and budgets of organochlorinated compounds in Northwest Mediterranean sediments. Environ. Sci. Technol. 29, 25192527.

Torres, M.A., Barros, M.P., Campos, S.C.G., Pinto, E., Rajamani, S., Sayre, R.T., Colepicolo, P., 2008. Biochemical biomarkers in algae and marine pollution: A review. Ecotox. Environ. Safety 71, 1-15.

Tournoud, M.G., Payraudeau, S., Cernesson, F., Salles, C., 2006. Origins and quantification of nitrogen inputs into a coastal lagoon: application to the Thau Lagoon (France). Ecol. Modelling 193, 9-33.

Trottet, A., Leboulanger, C., Vidussi, F., Pete, R., Bouvy, M., Fouilland, E., 2016. Heterotrophic bacteria show weak competition for nitrogen in Mediterranean coastal waters (Thau Lagoon) in autumn. Microbial Ecol. 71, 304-314. 
Utermöhl, H., 1958. Zur Vervollkommnung der quantitativen Phytoplankton-Methodik [For the perfection of quantitative phytoplankton methodology], Mitteilungen internationale Vereinigung Theoretische und Angewandte Limnologie [Communications of international symposium on theoretical and applied limnology] 9: 1-38.

Voie, $\varnothing$., Johnsen, A., Rossland, H., 2002. Why biota still accumulate high levels of PCB after removal of PCB contaminated sediments in a Norwegian fjord. Chemosphere 46, 1367-1372.

Wang, Y., Wang, J., Mu, J., Wang, Z., Yao, Z., Lin, Z., 2014. Aquatic predicted no-effect concentration for three polycyclic aromatic hydrocarbons and probabilistic ecological risk assessment in Liaodong Bay of the Bohai Sea, China. Environ. Sci. Poll. Res. 21, 148-158.

Wheeler, J.R., Leung, K.M.Y., Morritt, D., Sorokin, N., Rogers, H., Toy, R., Holt, M., Whitehouse, P., Crane, M. 2002. Freshwater to saltwater toxicity extrapolation using species sensitivity distributions. Environ. Toxicol. Assess. 21, 2459-2467.

Yan, W., Chi, J., Wang, Z., Huang, W., Zhang, G., 2009. Spatial and temporal distribution of polycyclic aromatic hydrocarbons (PAHs) in sediments from Daya Bay, South China. Environ. Poll. 157, 1823-1830. 